$$
\text { USGS/OFR-- 98-363 }
$$

U. S. DEPARTMENT OF THE INTERIOR

\section{REOEIVEO
SEP 041998 \\ OSTI}

\author{
U.S. GEOLOGICAL SURVEY
}

\title{
SCHLUMBERGER SOUNDINGS IN THE OASIS VALLEY \\ NEAR BEATTY, NEVADA
}

By

Robert J. Bisdorf'

Open-File Report 98-363

1998

This report is preliminary and has not been reviewed for conformity with U.S. Geological Survey editorial standards. Any use of trade, product, or firm names is for descriptive purposes only and does not constitute endorsement by the U.S. Government.

'Denver Federal Center, M.S. 964, Box 25046, Denver, CO 80225 


\section{DISCLAIMER}

This report was prepared as an account of work sponsored by an agency of the United States Government. Neither the United States Government nor any agency thereof, nor any of their employees, makes any warranty, express or implied, or assumes any legal liability or responsibility for the accuracy, completeness, or usefulness of any information, apparatus, product, or process disclosed, or represents that its use would not infringe privately owned rights. Reference herein to any specific commercial product, process, or setvice by trade name, trademark, manufacturer, or otherwise does not necessarily constitute or imply its endorsement, recommendation, or favoring by the United States Government or any agency thereof. The views and opinions of authors expressed herein do not necessarily state or reflect those of the United States Government or any agency thereof. 


\section{DISCLAIMER}

Portions of this document may be illegible in electronic image products. Images are produced from the best available original document. 
Schlumberger Soundings in the Oasis Valley near Beatty, Nevada.

by

Robert J. Bisdorf

In 1997 the U.S. Geological Survey made 36 direct current (dc) electrical soundings in the Oasis Valley near Beatty, Nevada, using the Schlumberger array. The soundings were made to determine the resistivity structure as an aid in evaluating the hydrologic conditions. The purpose of this report is to present the sounding data and its automatic interpretation.

Figure 1 is a map of the sounding locations, number and direction of expansion of the Schlumbegher array. The soundings are represented by circles and the direction of expansion by short bold lines adjacent to the circles. Table 1 gives the sounding number, $x$ coordinate, $y$ coordinate, and elevation of the soundings. The $x$ and $y$ coordinates are in kilometers UTM zone 11 using the North America horizontal datum of 1927. The elevations are in feet using the North American vertical datum of 1929.

\section{RESISTIVITY SOUNDING}

Schlumberger sounding is a geophysical technique that uses variations in the electrical resistivity of earth materials to help detect buried geologic structures. DC resistivity (the inverse of conductivity) is a fundamental rock property that varies due to rock type, clay content, porosity and the quantity and quality of the water contained in the rock. Resistivity is normally expressed in ohm-m. Within a given rock type, the resistivity of the rock is primarily dependant on the quality and quantity of water and the amount of clay present. Generally speaking, higher clay content and/or poorer quality (higher TDS and/or chlorides) ground water lowers the rock resistivity.

Schlumberger sounding uses a symmetric electrode array to vertically explore the subsurface. The name Schlumberger derives from Conrad Schlumberger, an early proponent of the array geometry. Schlumberger soundings are processed by computer modeling of the sounding data as a series of horizontal layers (Zohdy, 1989 and Zohdy and Bisdorf, 1989). More detailed explanations of processing and automatic interpretation procedure can be found in Bisdorf (1985) and Zohdy and others (1993). A series of individual soundings can be combined to generate a geoelectrical cross section of interpreted resistivity. Cross sections, which can be thought of as vertical slices through the ground, similar to a road cut, are easier to interpret than individual soundings and show lateral as well as vertical variations of resistivity.

The data were interpreted using an automatic computerized interpretation program (Zohdy and Bisdorf, 1989) written for IBM PC's and compatible computers. The soundings are designated OASIS 1 through OASIS 36 . For each sounding curve, the data in the appendix includes:

1) A sounding title designated by the name of the survey area followed by the sounding number. Several sounding titles have the suffix $S$ denoting that the field 


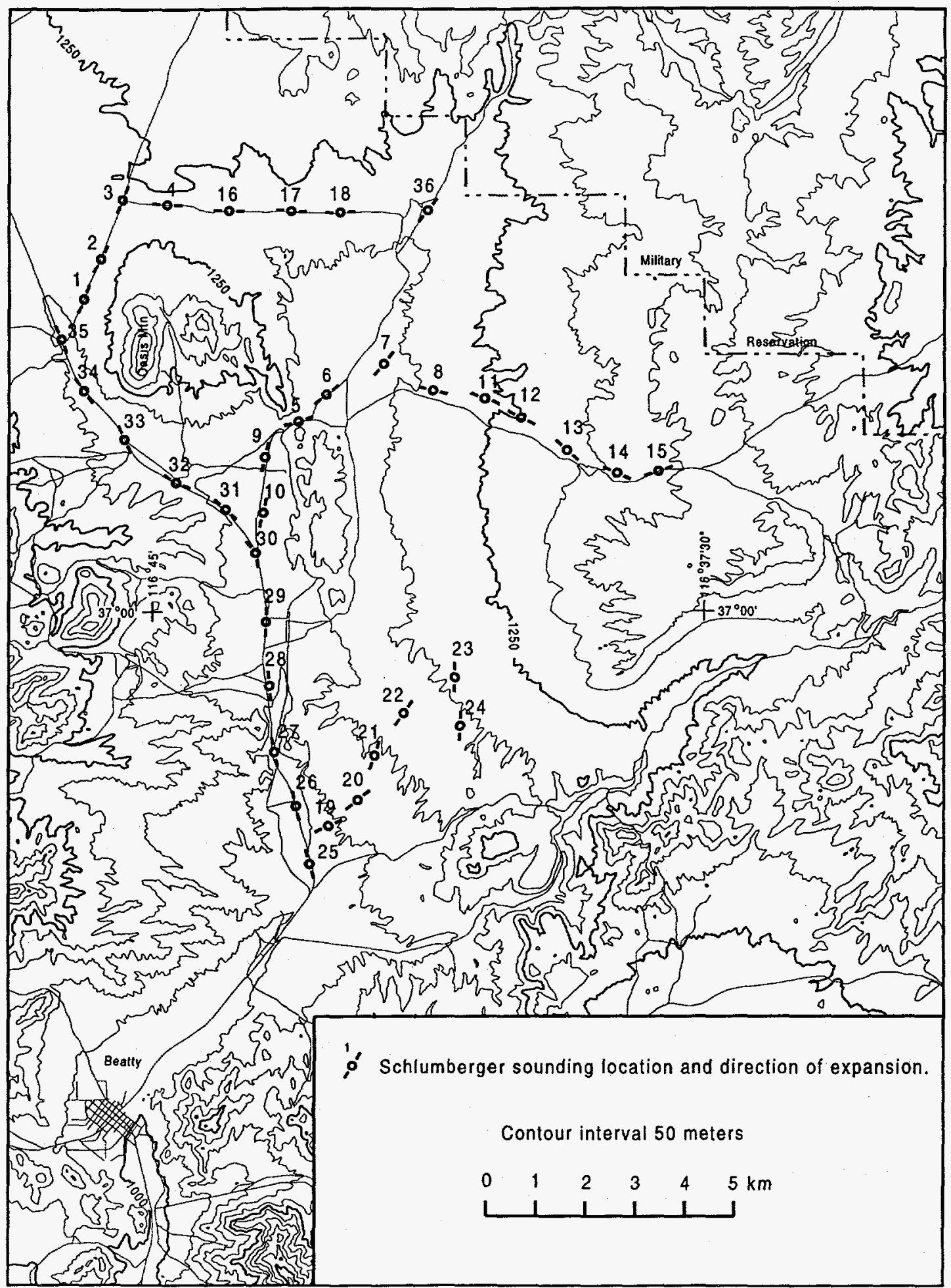

Figure 1. Map showing the location, number, and direction of expansion of the Schlumberger soundings. 


\begin{tabular}{|c|c|c|c|}
\hline $\begin{array}{c}\text { Sounding } \\
\text { Number }\end{array}$ & $\begin{array}{c}\mathrm{x} \\
(\mathrm{km})\end{array}$ & $\begin{array}{c}\mathrm{y} \\
(\mathrm{km})\end{array}$ & $\begin{array}{c}\text { Elevation } \\
(\mathrm{feet})\end{array}$ \\
\hline 1 & 520.84 & 4101.00 & 4010. \\
\hline 2 & 521.18 & 4101.80 & 4050. \\
\hline 3 & 521.62 & 4102.99 & 4065. \\
\hline 4 & 522.52 & 4102.89 & 4040. \\
\hline 5 & 525.17 & 4098.55 & 3800. \\
\hline 6 & 525.74 & 4099.08 & 3845. \\
\hline 7 & 526.90 & 4099.70 & 3900. \\
\hline 8 & 527.89 & 4099.16 & 3960. \\
\hline 9 & 524.50 & 4097.83 & 3750. \\
\hline 10 & 524.46 & 4096.71 & 3705. \\
\hline 11 & 528.94 & 4099.00 & 4040. \\
\hline 12 & 529.66 & 4098.62 & 4100. \\
\hline 13 & 530.59 & 4097.96 & 4190. \\
\hline 14 & 531.59 & 4097.50 & 4270. \\
\hline 15 & 532.42 & 4097.54 & 4360. \\
\hline 16 & 523.77 & 4102.77 & 3995. \\
\hline 17 & 525.02 & 4102.77 & 4020. \\
\hline 18 & 526.01 & 4102.74 & 3980. \\
\hline
\end{tabular}

\begin{tabular}{|c|c|c|c|}
\hline $\begin{array}{c}\text { Sounding } \\
\text { Number }\end{array}$ & $\begin{array}{c}\mathrm{x} \\
(\mathrm{km})\end{array}$ & $\begin{array}{c}\mathrm{y} \\
(\mathrm{km})\end{array}$ & $\begin{array}{c}\text { Elevation } \\
(\mathrm{feet})\end{array}$ \\
\hline 19 & 525.79 & 4090.39 & 3580. \\
\hline 20 & 526.38 & 4090.91 & 3670. \\
\hline 21 & 526.72 & 4091.81 & 3750. \\
\hline 22 & 527.31 & 4092.66 & 3835. \\
\hline 23 & 528.34 & 4093.38 & 3960. \\
\hline 24 & 528.45 & 4092.41 & 3925. \\
\hline 25 & 525.41 & 4089.63 & 3515. \\
\hline 26 & 525.13 & 4090.80 & 3525. \\
\hline 27 & 524.70 & 4091.88 & 3580. \\
\hline 28 & 524.60 & 4093.21 & 3620. \\
\hline 29 & 524.53 & 4094.50 & 3635. \\
\hline 30 & 524.31 & 4095.90 & 3700. \\
\hline 31 & 523.70 & 4096.77 & 3740. \\
\hline 32 & 522.71 & 4097.30 & 3795. \\
\hline 33 & 521.66 & 4098.18 & 3870. \\
\hline 34 & 520.84 & 4099.16 & 3890. \\
\hline 35 & 520.38 & 4100.19 & 3925. \\
\hline 36 & 527.78 & 4102.78 & 3960. \\
\hline
\end{tabular}

Table 1. Schlumberger sounding coordinates. Horizontal coordinates ( $x$ and $y$ ) are in kilometers UTM zone 11 using the North American horizontal datum of 1927. Elevations are in feet using the North American vertical datum of 1929. 
data were smoothed before the inversion was performed. Only the interpreted sounding titles will have suffixes.

2) A tabulation of the $A B / 2$ electrode spacings (in meters and feet) and corresponding apparent resistivities (in ohm-meters).

3) A log-log plot of the field data points. Each set of data points that were made with the same potential electrode spacing (MN) is connected with a solid line. Measurements were made at MN/2 spacings of .6,2, 20,60, and 200 feet as appropriate.

4) A tabulation of the automatically interpreted layering, with depths in meters and feet and the corresponding resistivity values in ohm-meters.

5) A log-log plot of the results of the automatic interpretation program. The circles represent the shifted-digitized field data, the continuous curve represents the sounding curve calculated from the interpreted layering, and the step-function curve represents the interpreted layering.

\section{RESISTIVITY CROSS SECTIONS}

Resistivity cross sections are generated from individual sounding interpretations. Each sounding interpretation is sampled in a manner to approximate a continuous vertical distribution of resistivity with depth (Bisdorf, 1982). This vertical data is then horizontally interpolated to create a grid. Color values are assigned based on the interpolated resistivity values and the desired contour levels. Triangles on the upper surface of the cross section designate the sounding locations. Topographic information, input as sounding elevations, is represented by connecting the surface location of the soundings by straight lines. The cross sections are vertically exaggerated five times.

The color scale shows interpreted resistivities ranging from low resistivities $(<7$ ohm-m) in the cool colors (blues and greens) to high resistivities (>300 ohm-m) in the warm colors (yellow-red). As a general guide to interpreting the cross sections, the following correlation between resistivity range and possible earth material is given: 
less than $10 \mathrm{ohm}-\mathrm{m}$

10 to $45 \mathrm{ohm}-\mathrm{m}$

45 to $150 \mathrm{ohm}-\mathrm{m}$

greater than $150 \mathrm{ohm}-\mathrm{m}$
Fine grained clay rich sediments (saturated or unsaturated), altered volcanic rocks.

saturated alluvium, zeolitized volcanic rocks

unsaturated alluvium, non- to moderately- welded tuff or rhyolite

moderately- to densely- welded tuff, other volcanic rocks

Figure 2 shows a resistivity cross section that is oriented predominately eastwest. On the west side of the cross section, under soundings 35,1 and 2 , is a zone with resistivities of 45 to $150 \mathrm{ohm}-\mathrm{m}$ starting at a depth of about $150 \mathrm{~m}$. This zone probably represents a non- to moderately- welded tuff.

Figure 3 shows a resistivity cross section again oriented predominately eastwest. A shallow zone under soundings $8,11,12$, and 13 has resistivities greater than $150 \mathrm{ohm}-\mathrm{m}$ and probably represent unsaturated alluvium. The 45 to $150 \mathrm{ohm}-\mathrm{m}$ material present under soundings 9,5 , and 6 is representative of a non- to moderatelywelded tuff. This material extends to greater than $250 \mathrm{~m}$ depth under soundings 5 and 6. The 45 to $150 \mathrm{ohm}-\mathrm{m}$ material present under sounding 15 at a depth of about $150 \mathrm{~m}$ probably represents a rhyolite or ash flow tuff.

Figure 4 shows a resistivity cross section that is oriented north-south along the Amargosa River. The 45 to $150 \mathrm{ohm}-\mathrm{m}$ material present under soundings 33 and 32 is representative of a non- to moderately- welded tuff. Under sounding 27 and somewhat under sounding 26 is a zone of resistivities of 45 to greater than $150 \mathrm{ohm}-\mathrm{m}$. This zone is probably represents a moderately- to highly- welded tuff, dense rhyolite or other competent material. This unit has a higher resistivity possibly due to high quartz content or reduced porosity.

Figure 5 shows a northeast-southwest oriented cross section. The high $(>150$ ohm-m) and moderately high ( 45 to $150 \mathrm{ohm}-\mathrm{m}$ ) resistivity materials in the upper $20 \mathrm{~m}$ of the cross section represent unsaturated alluvium. The 45 to $150 \mathrm{ohm}-\mathrm{m}$ material deeper than $20 \mathrm{~m}$ represents unsaturated alluvium or non- to moderately- welded tuff. 


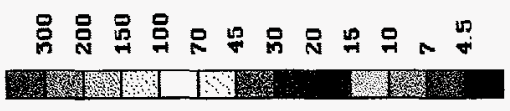

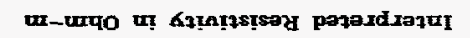

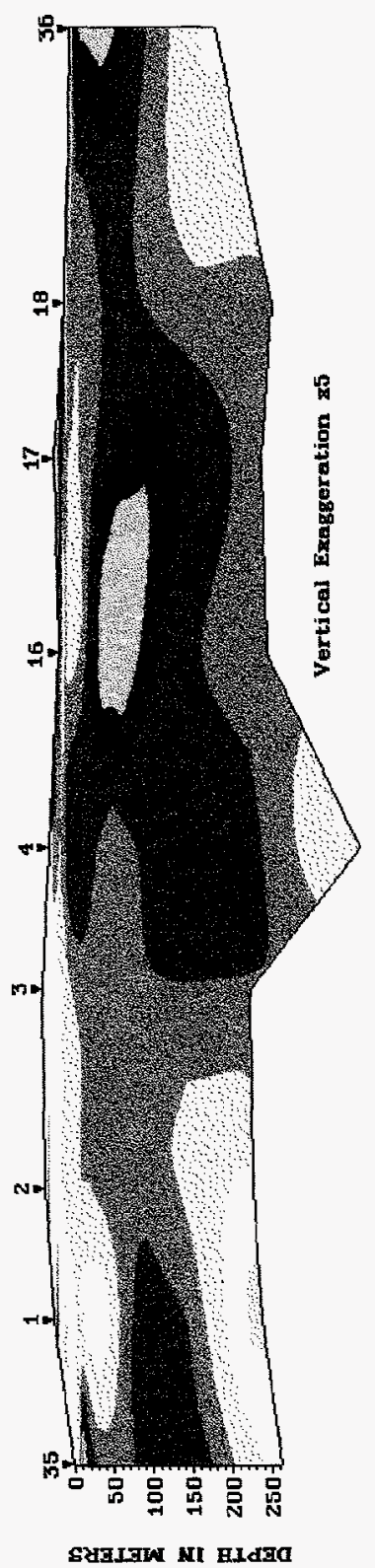

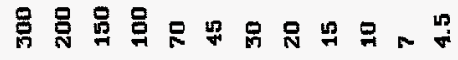

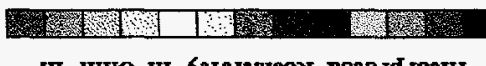

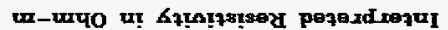

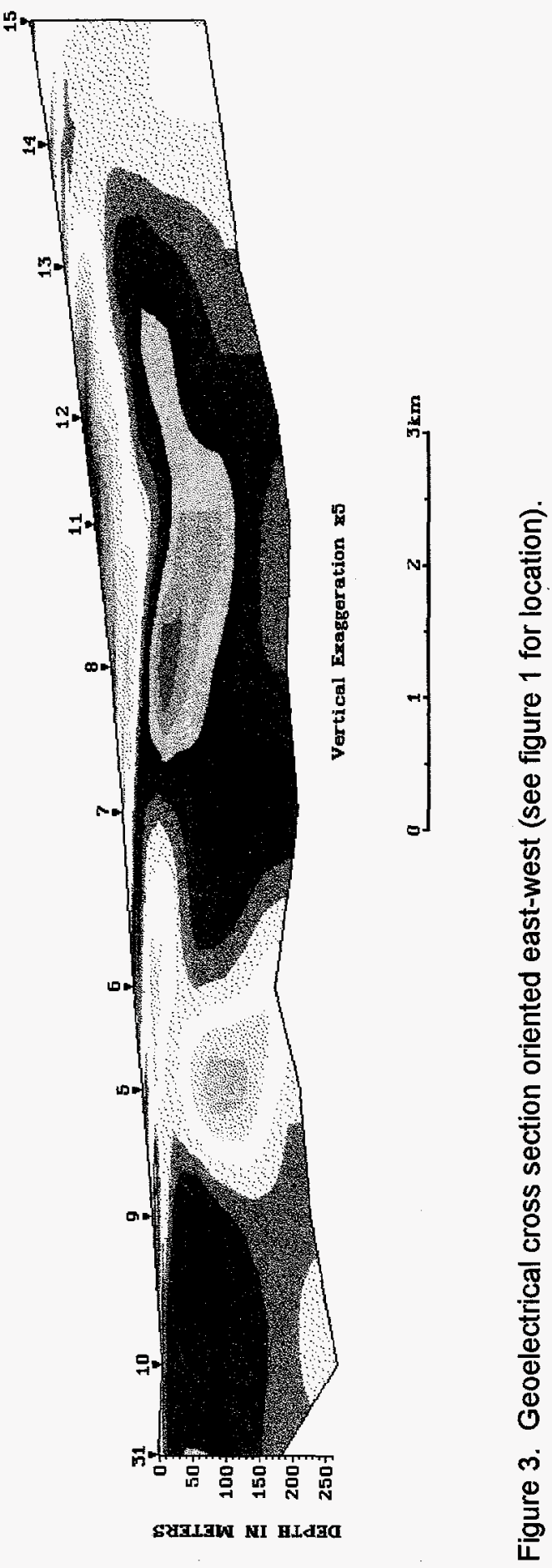




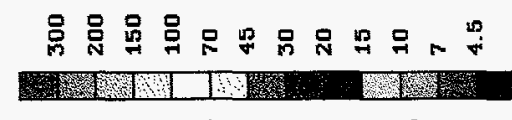

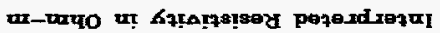

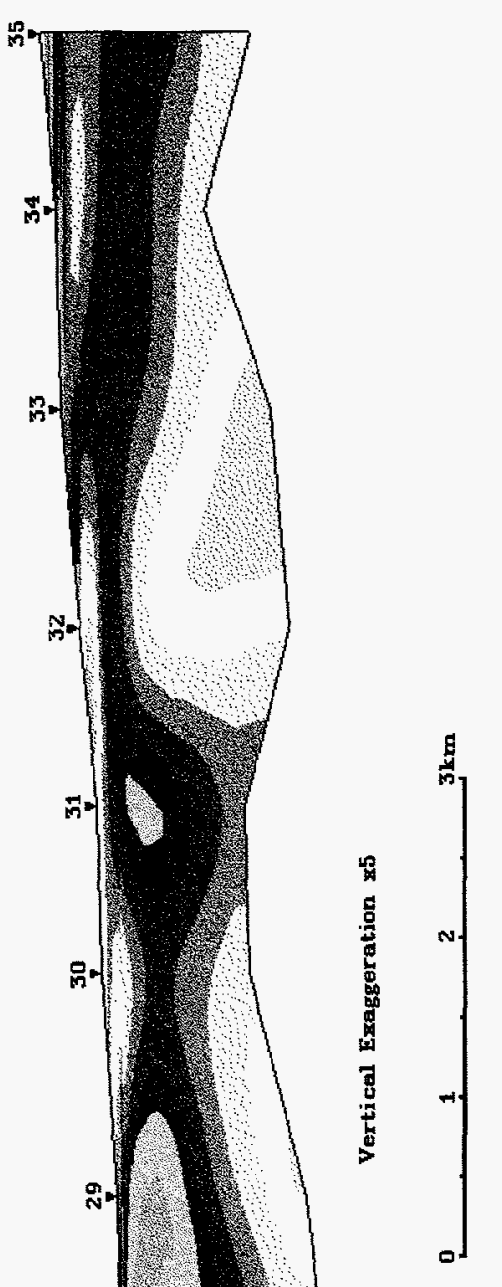

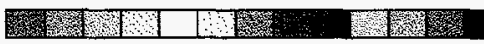

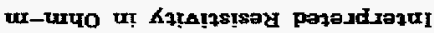
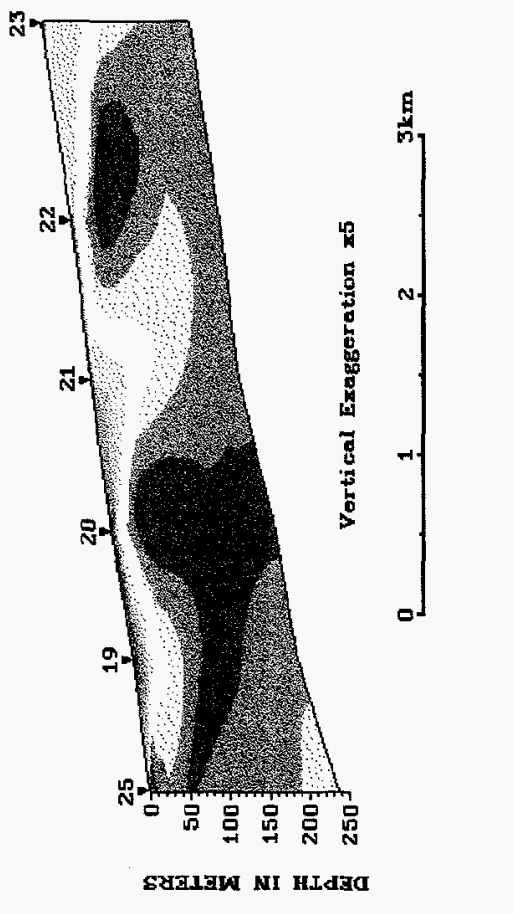

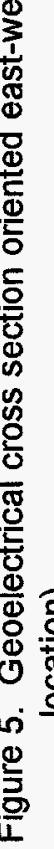




\section{REFERENCES}

Bisdorf, R.J., 1982, Schlumberger sounding investigations in the Date Creek Basin, Arizona: U.S. Geological Survey Open-File Report 82-953, 55 p.

_, 1985, Electrical techniques for engineering applications: Bulletin of the Association of Engineering Geologists, v. XXII, no. 4, p. 421-433.

Zohdy, A.A.R., 1989, A new method for the automatic interpretation of Schlumberger and Wenner sounding curves: Geophysics, v. 54, p. 245-253.

Zohdy, A. A. R., and Bisdorf, R. J., 1989, Programs for the automatic processing and interpretation of Schlumberger sounding curves in QuickBASIC 4.0: U.S. Geological Survey Open-File Report, 89-137 A\&B, 64 p. + diskette.

Zohdy, A.A.R., Bisdorf, R.J., and Martin, Peter, 1993, A study of sea-water intrusion using Schlumberger soundings near Oxnard, California: U.S. Geological Survey Open-File Report 93-524, 139 p.

\section{APPENDIX}



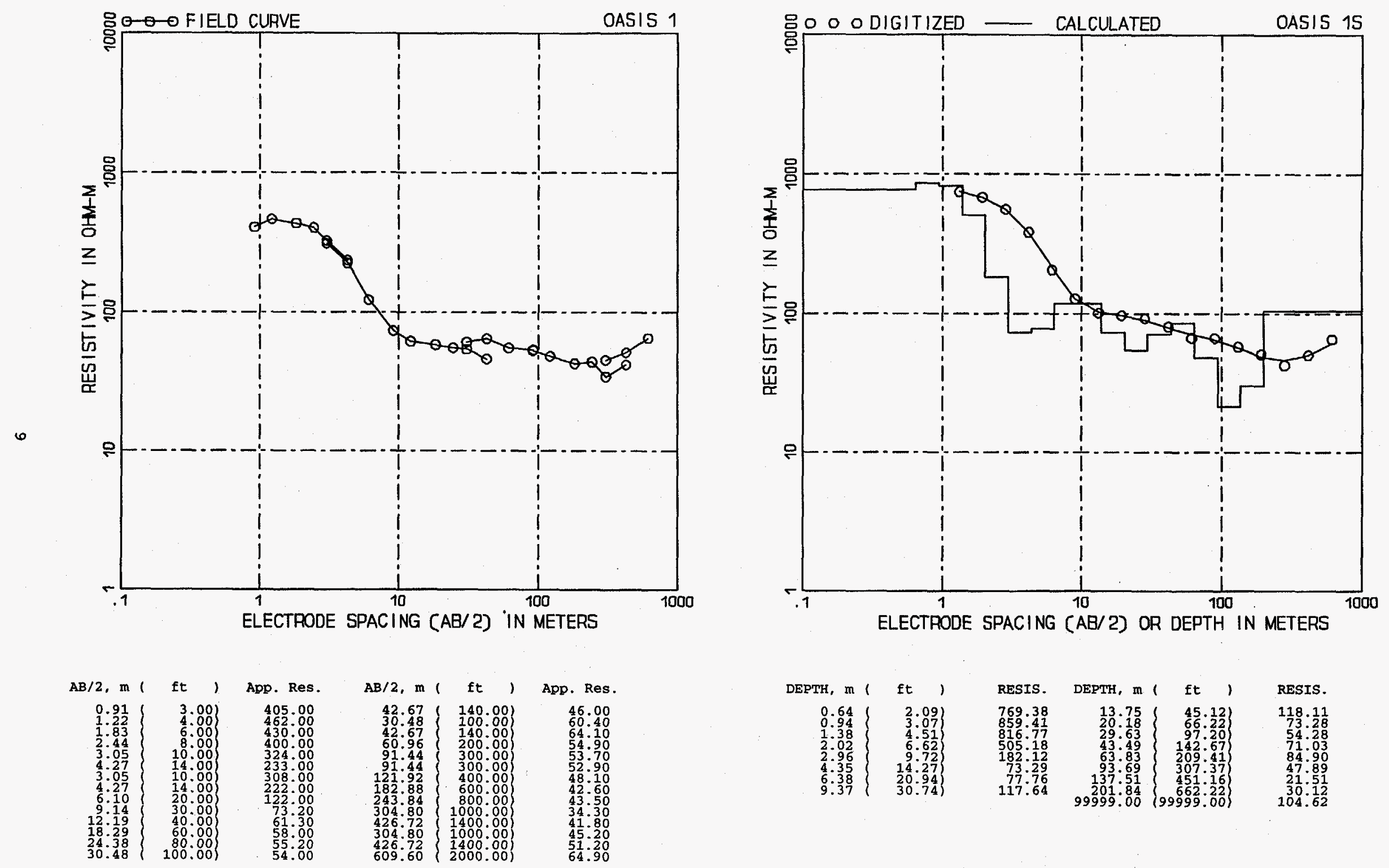

RESIS.

118.11 

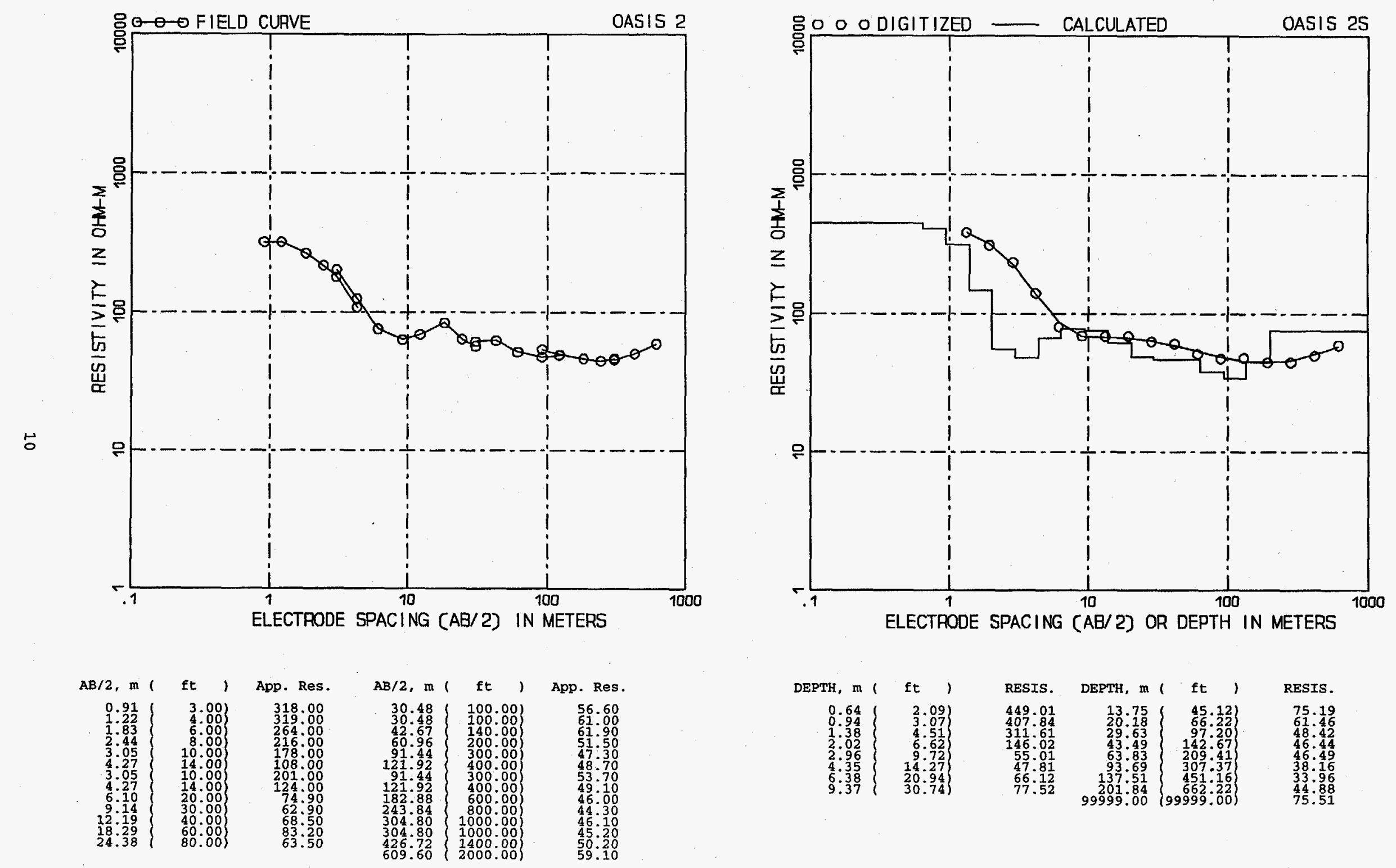

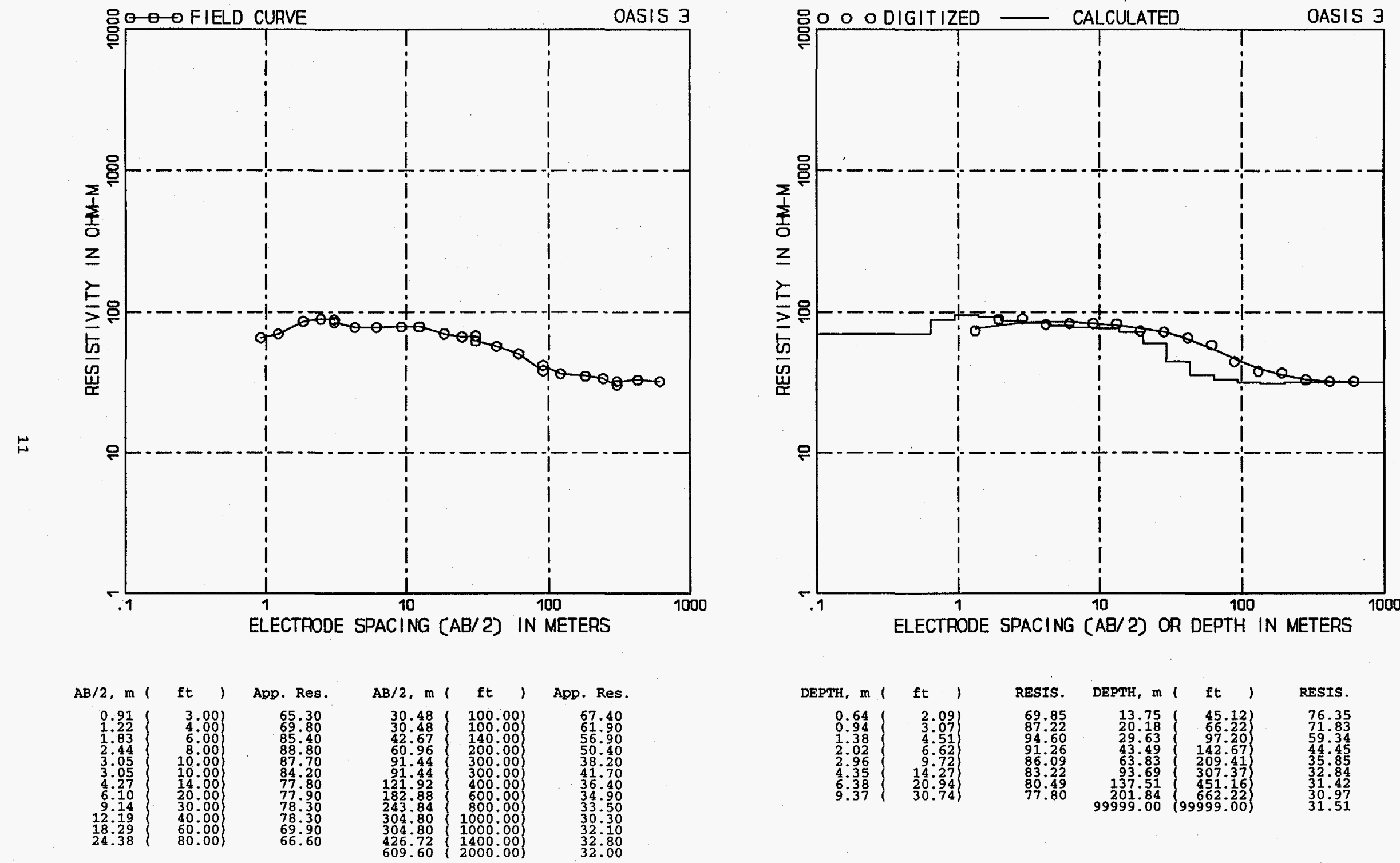

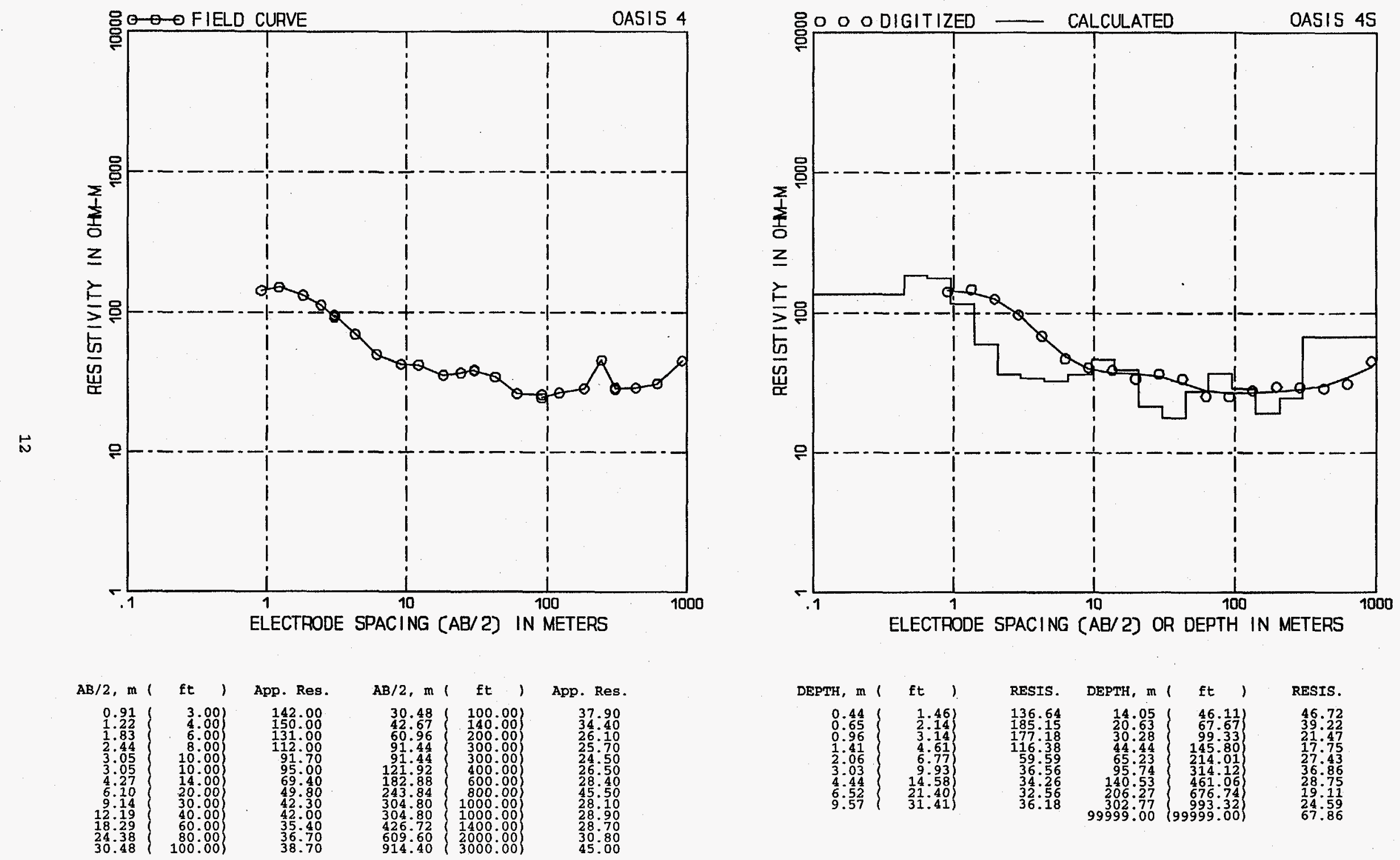

RESIS.

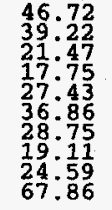



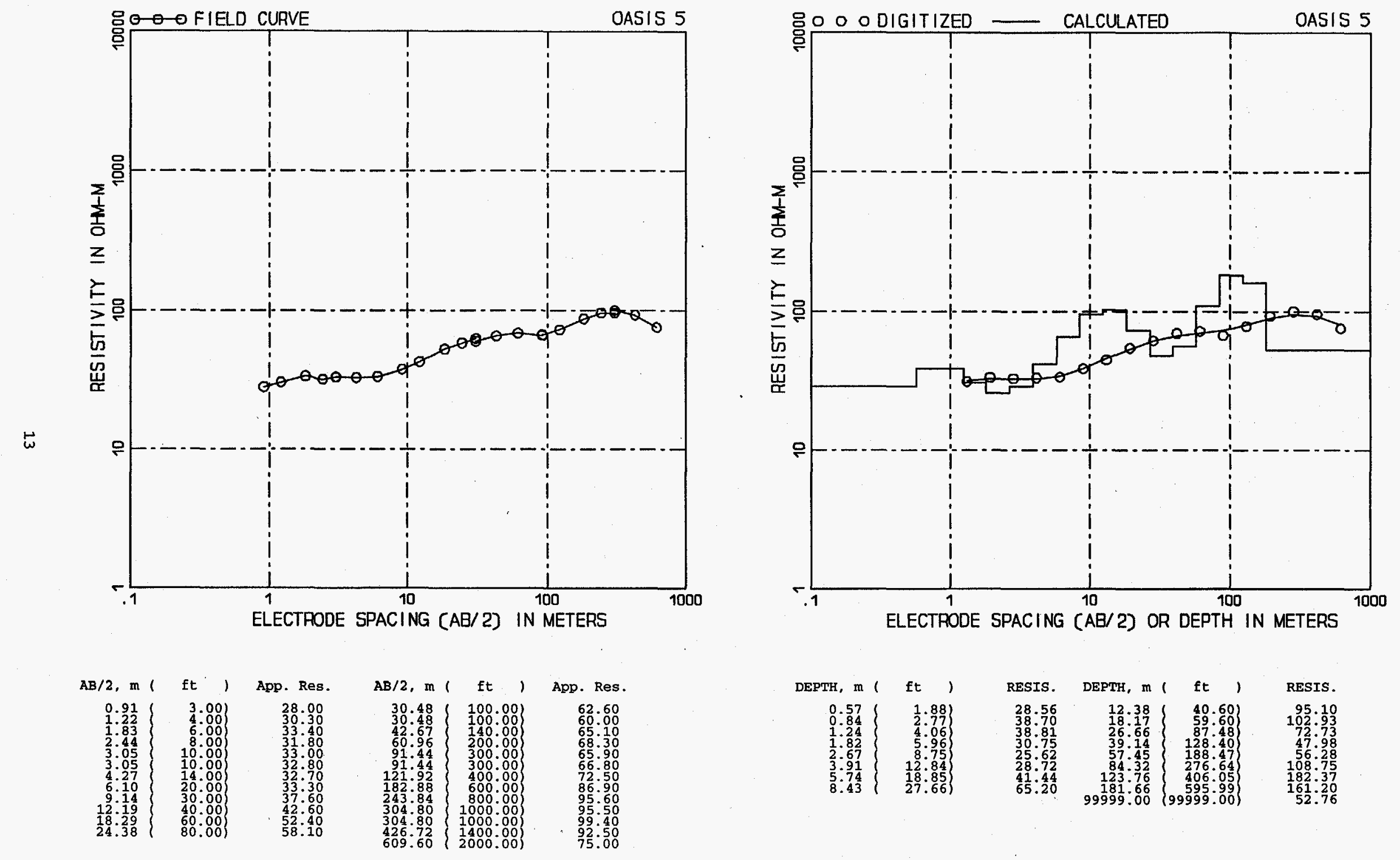

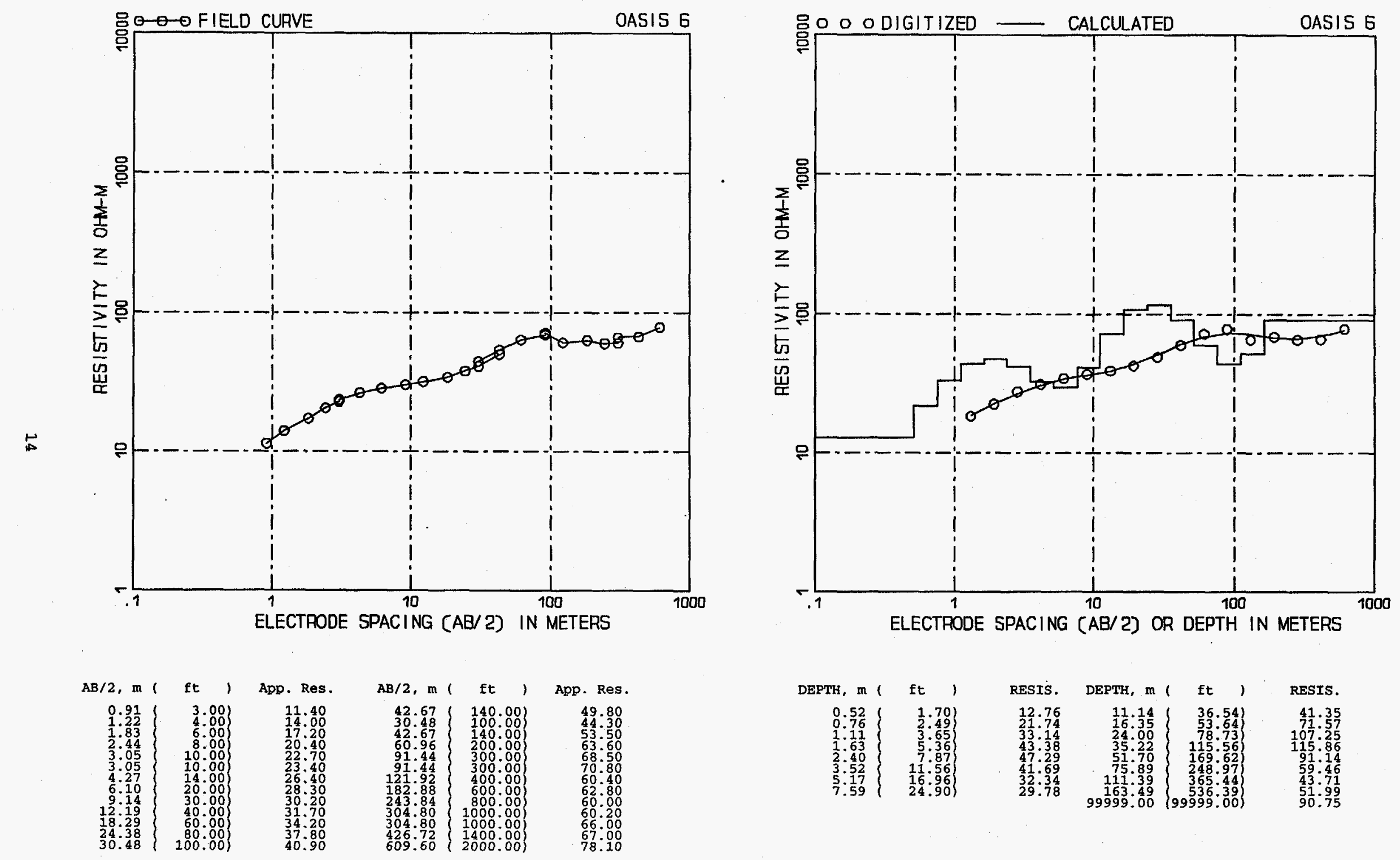

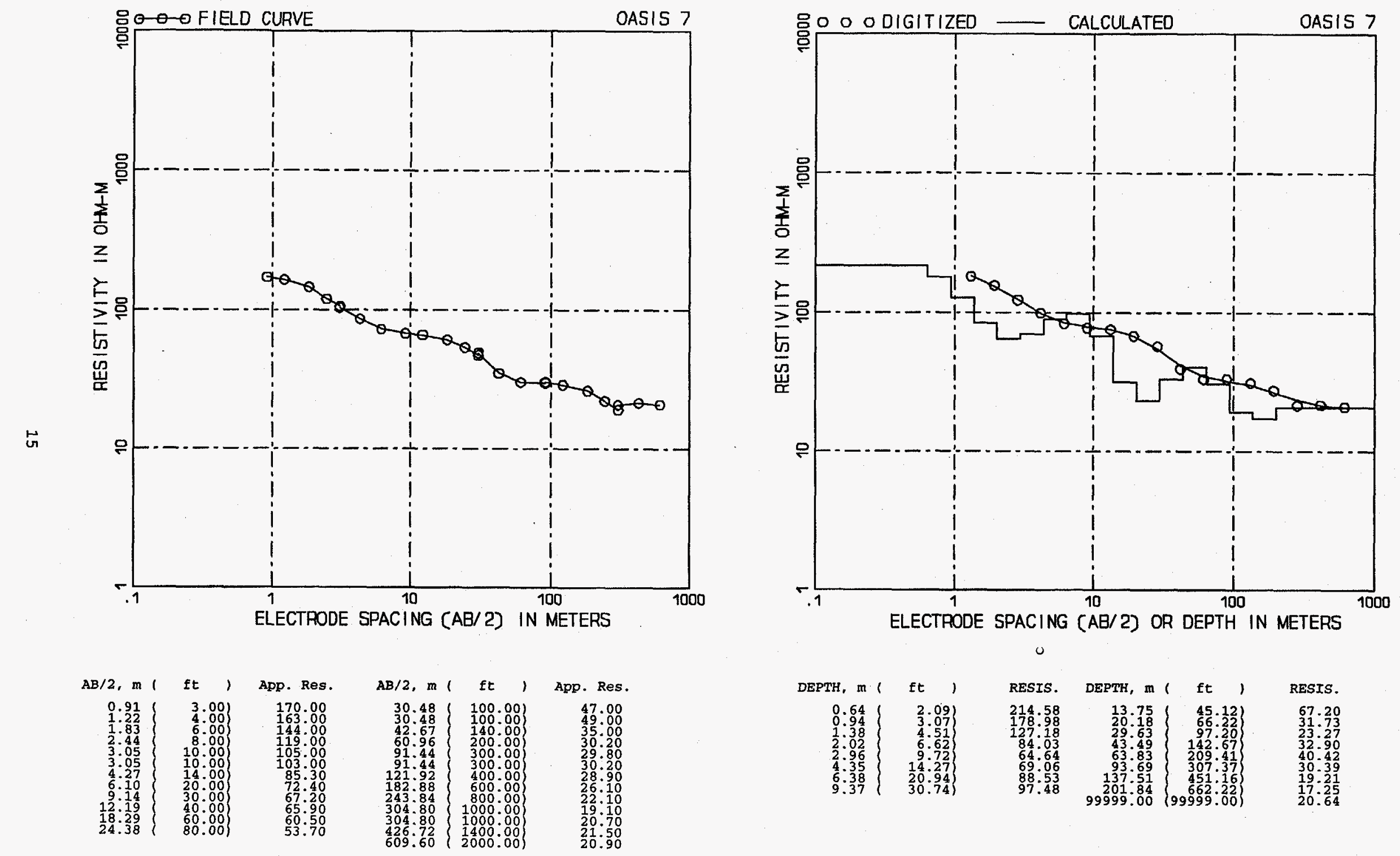

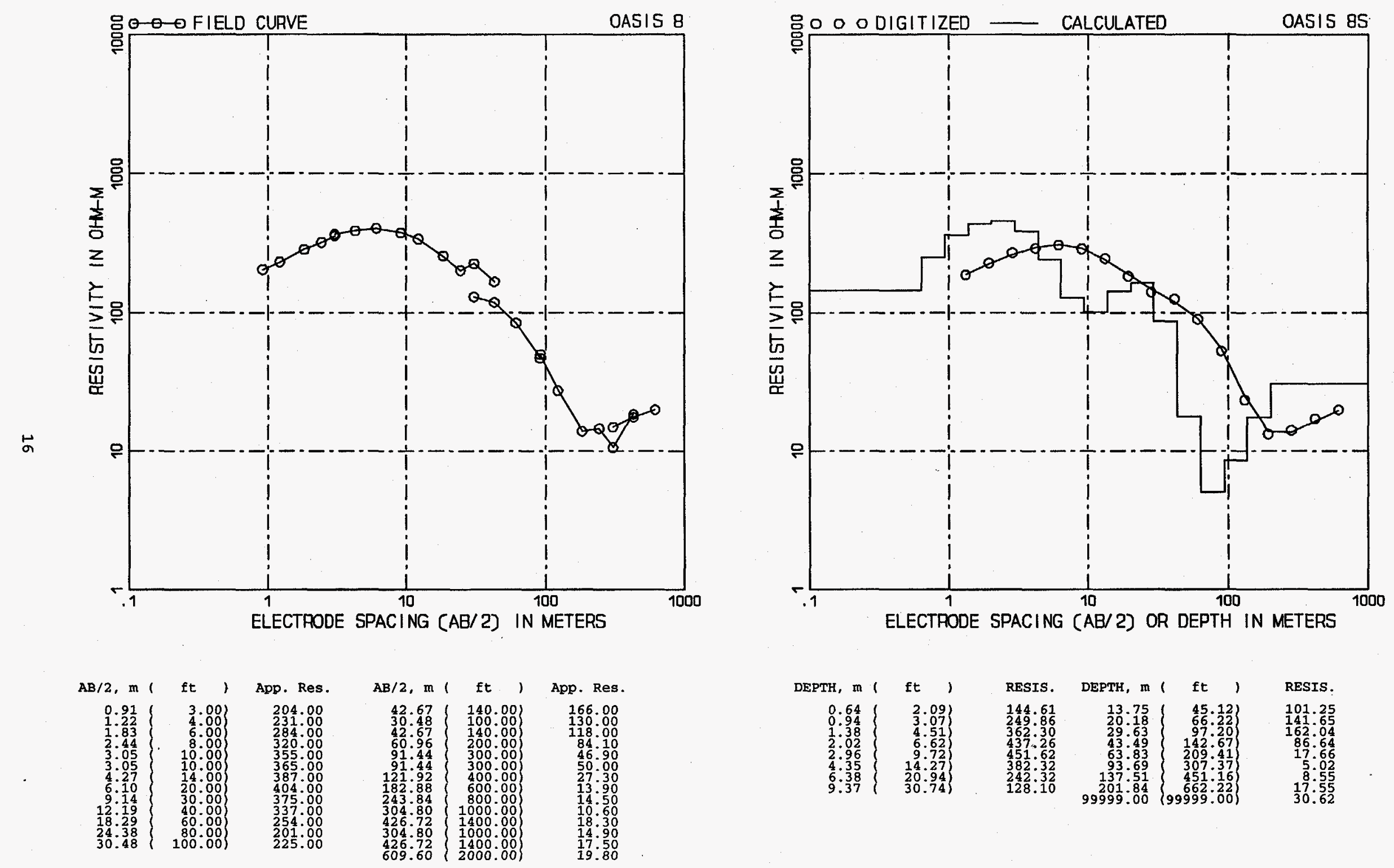

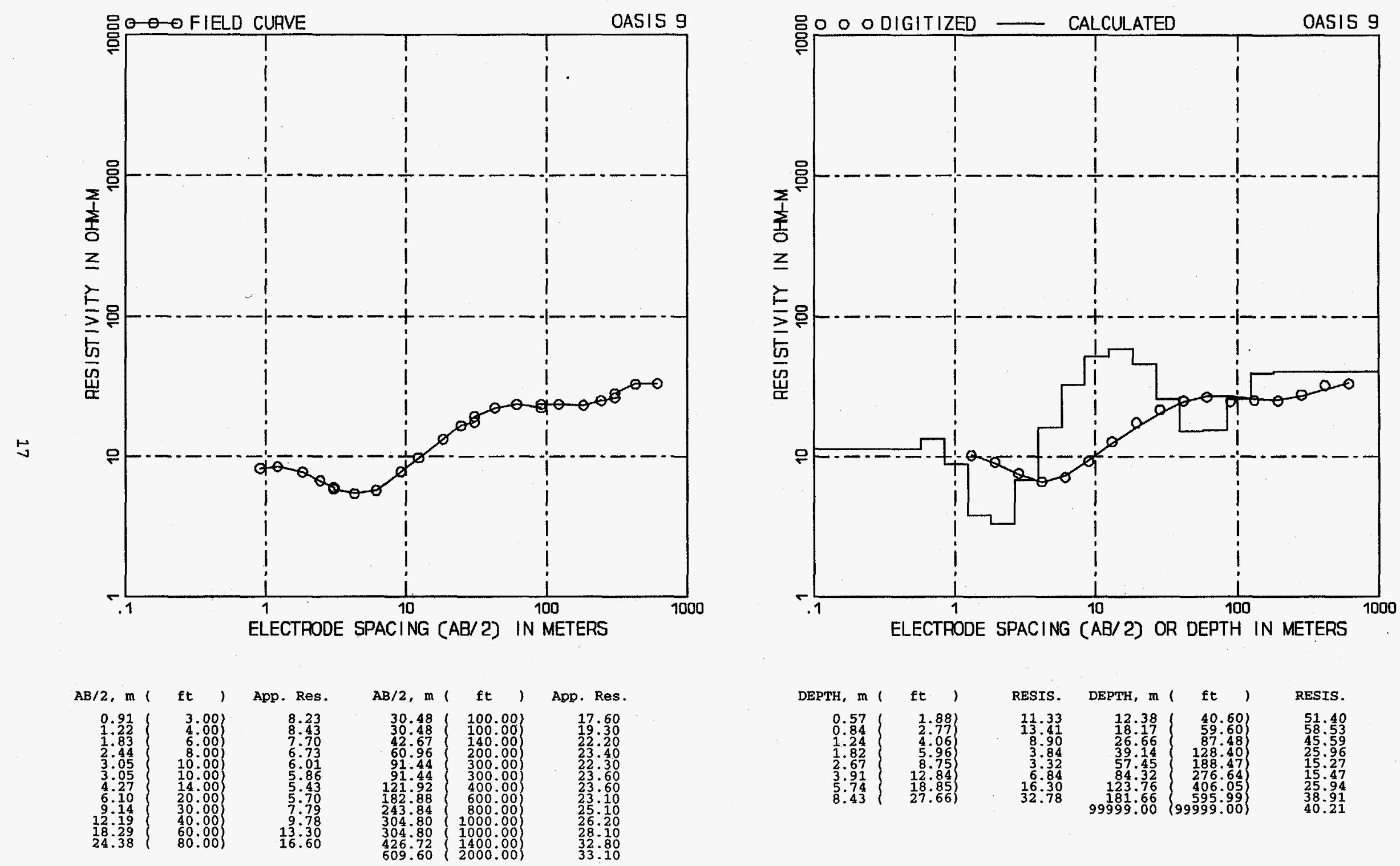

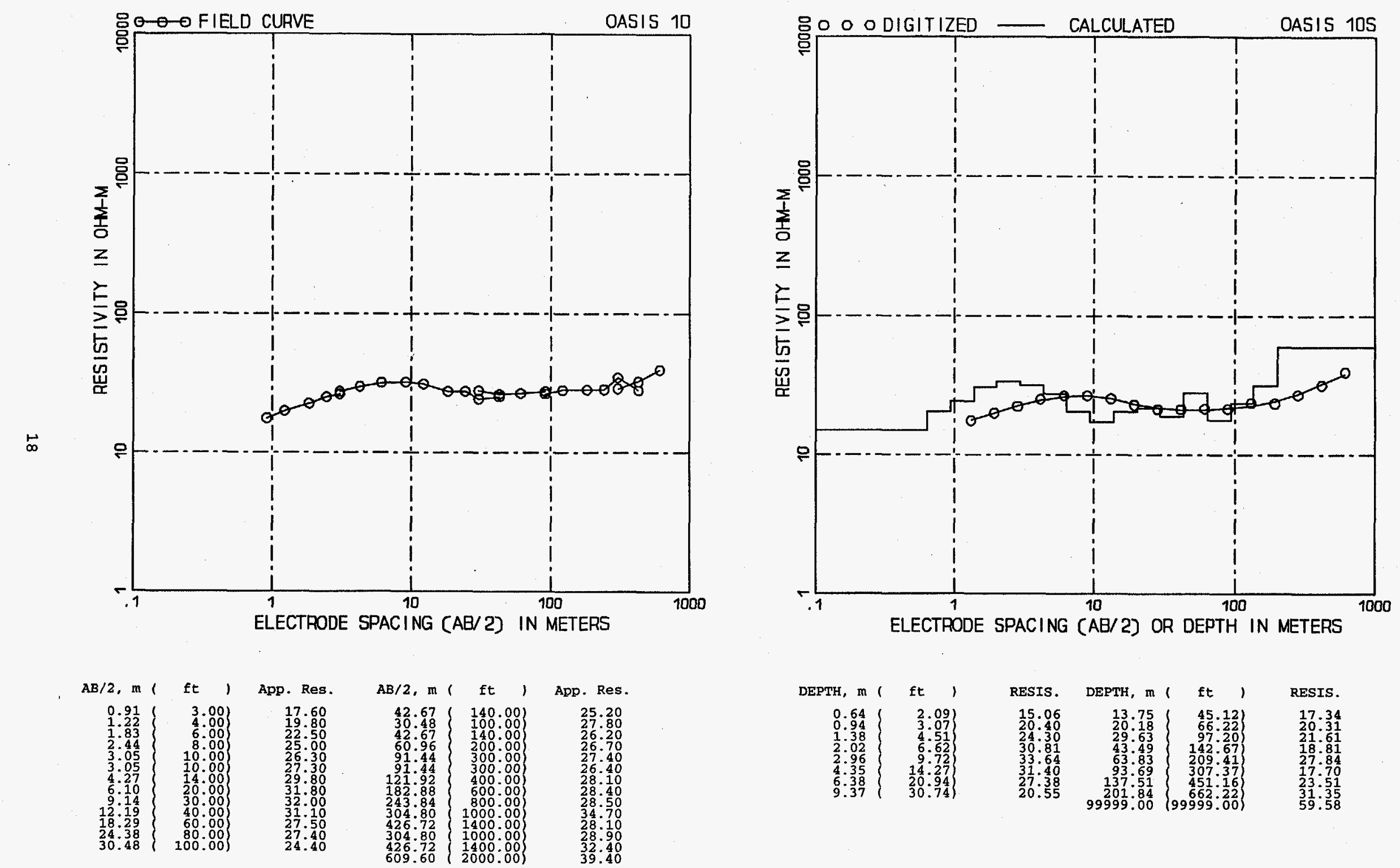

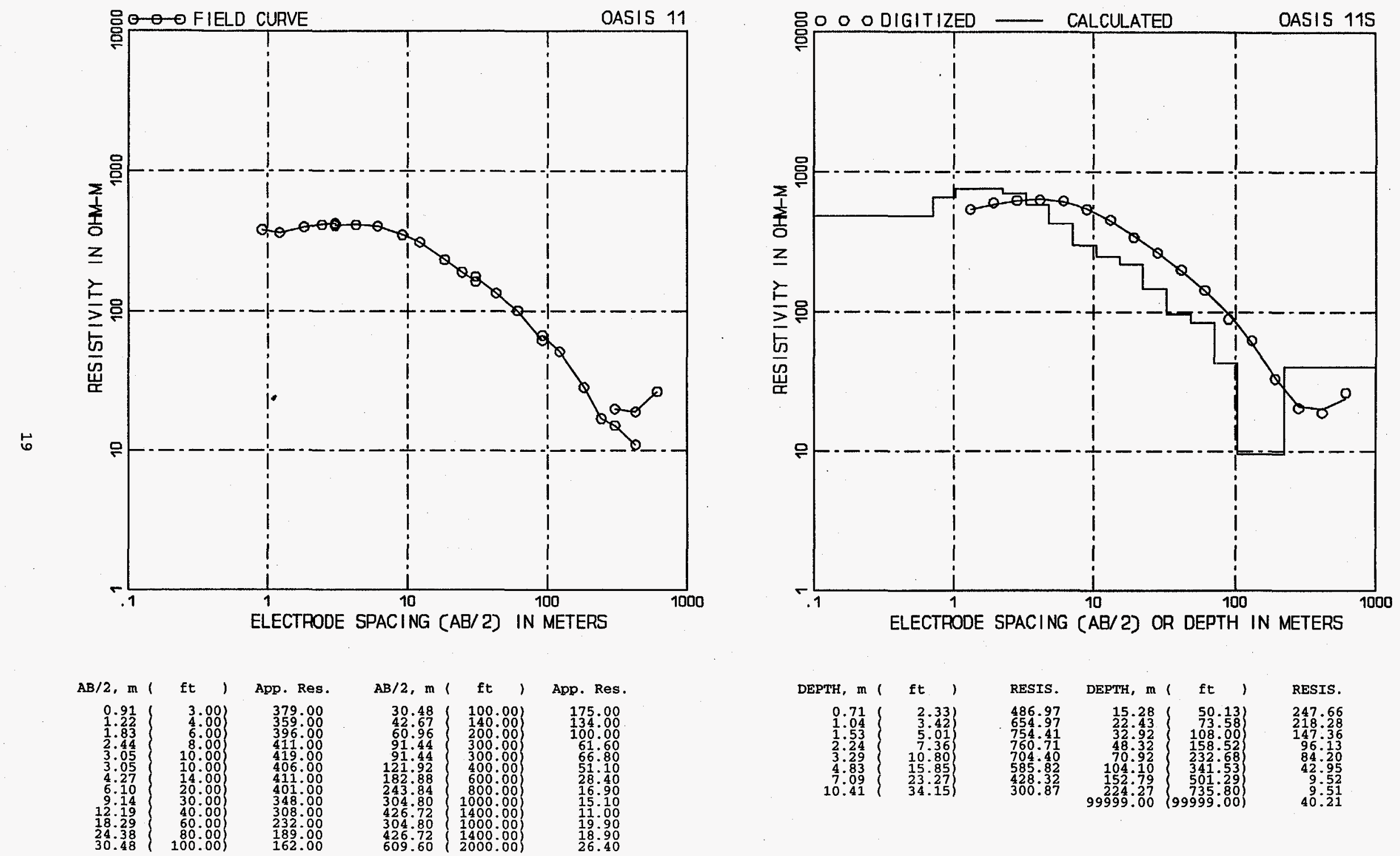

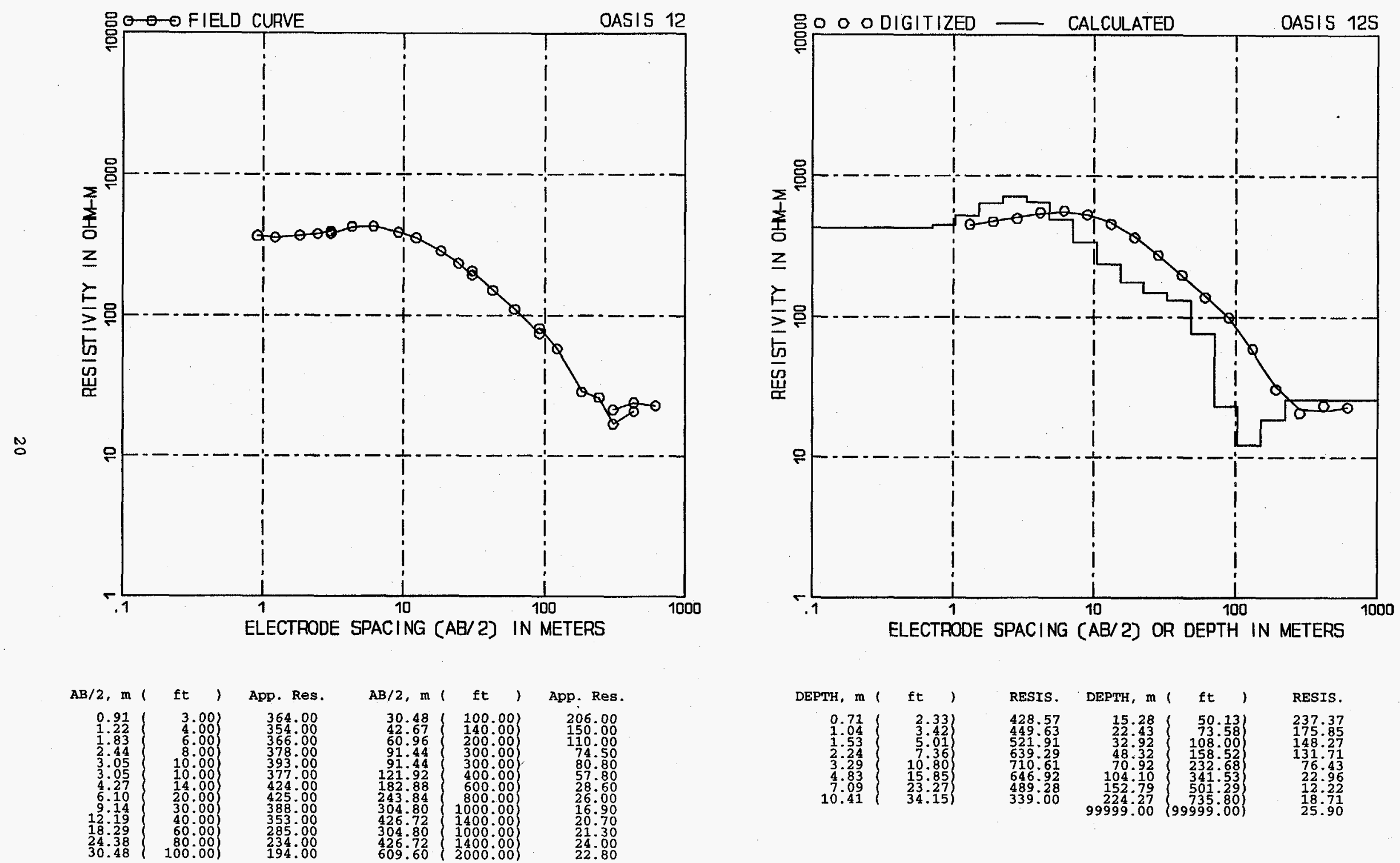

RESIS.

$224: 27$
$9999: 00$
$99999: 800$

237. 37

148.27
131.71
75.7

12.72
25.71
5.90 

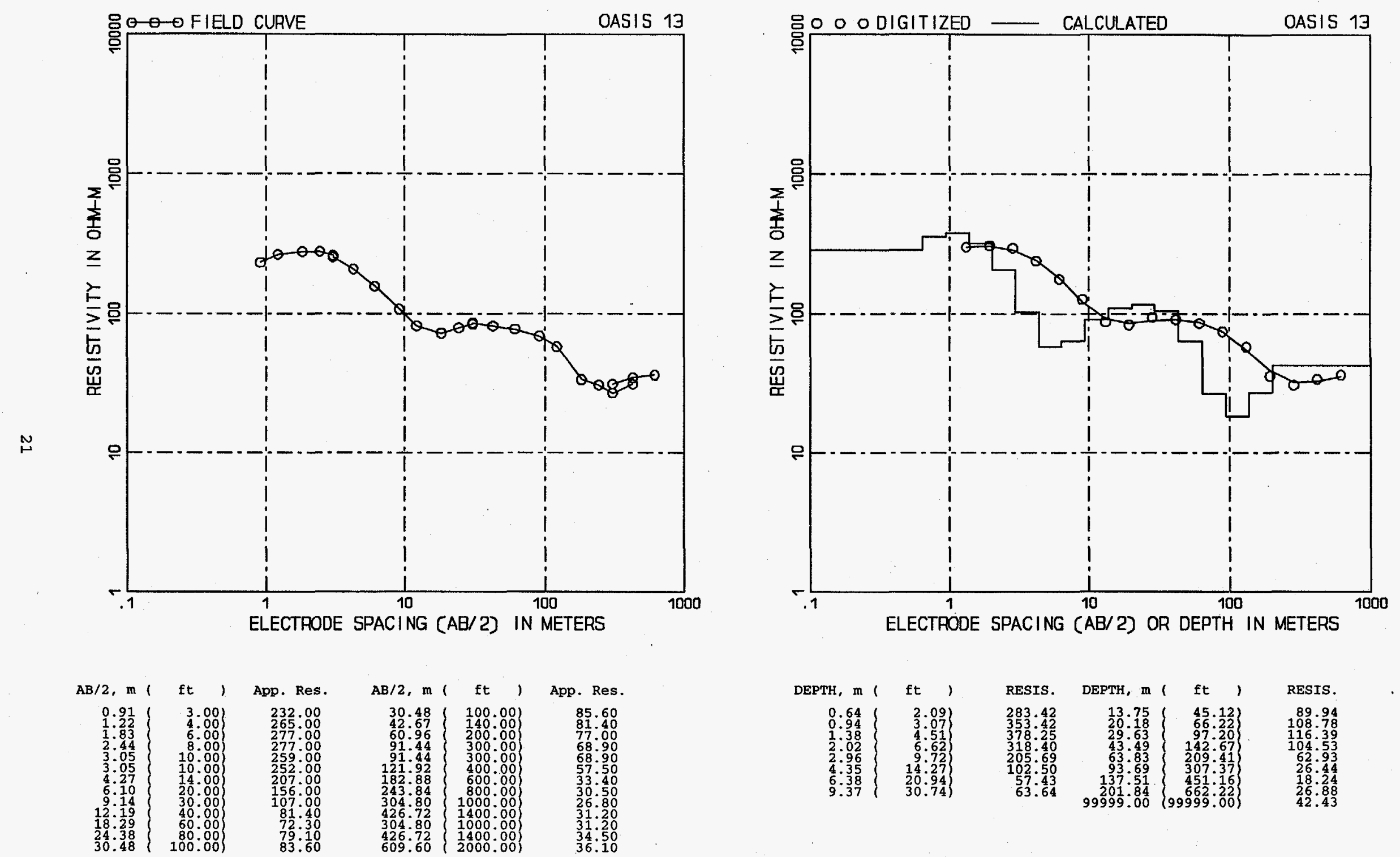

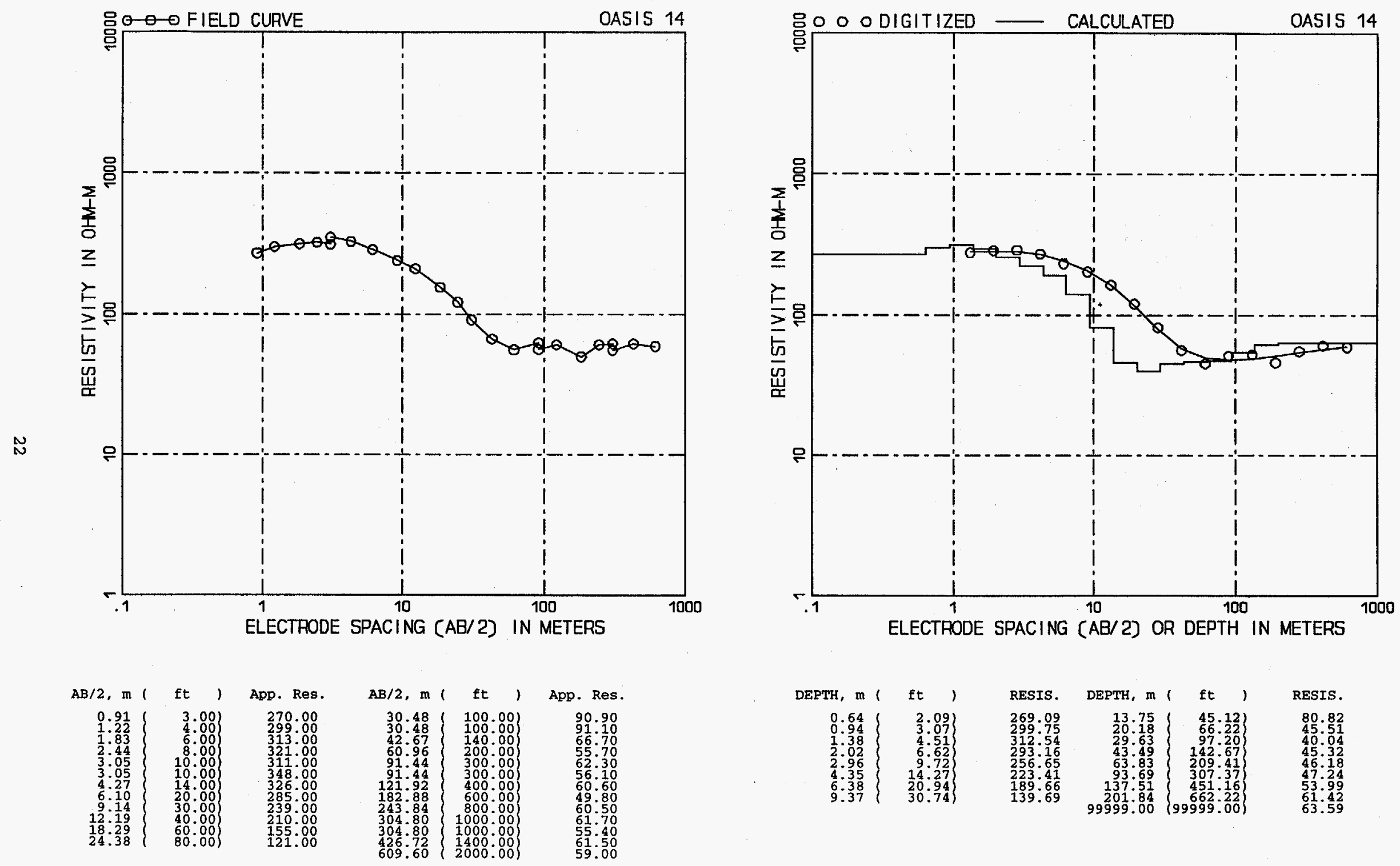

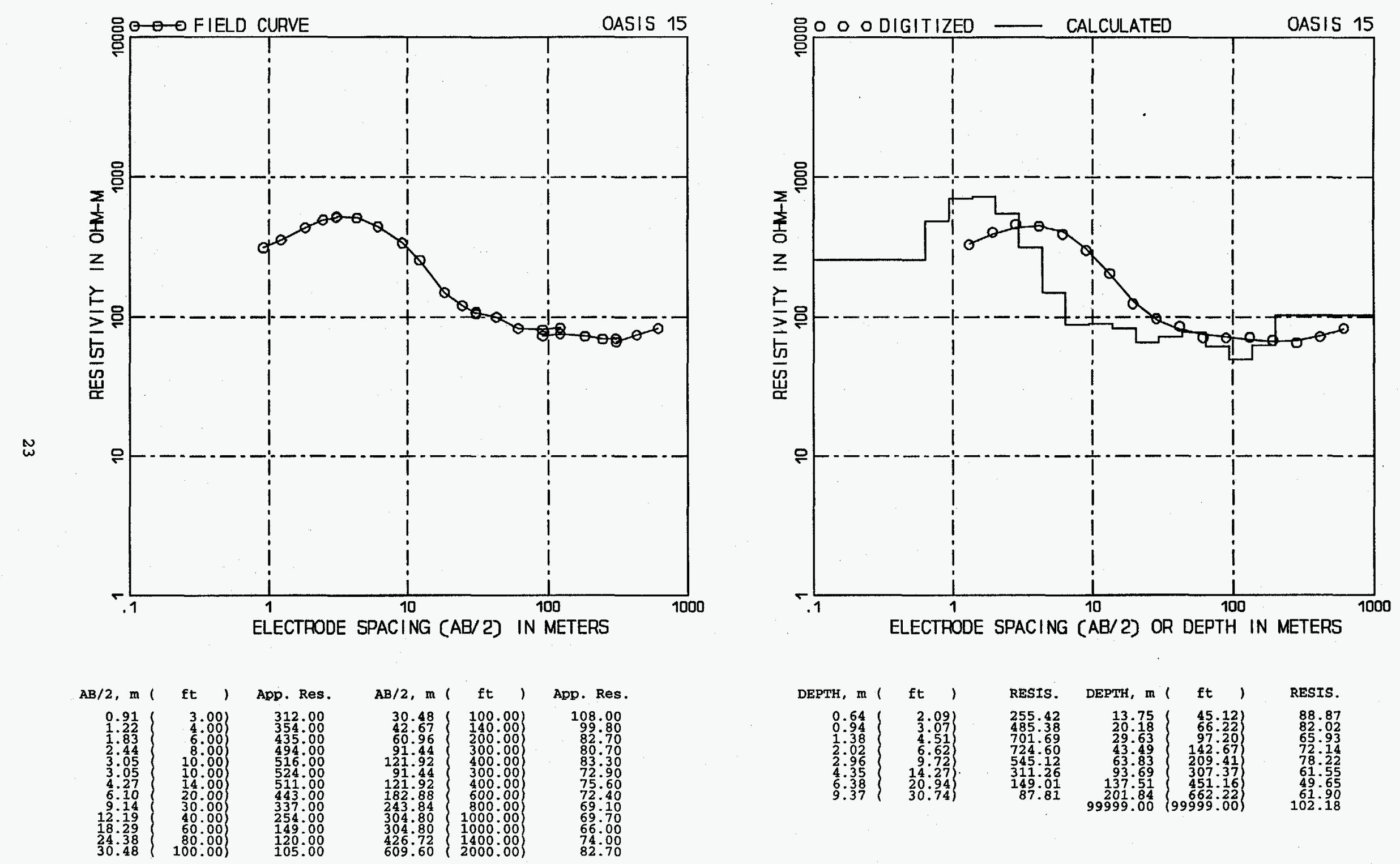

RESIS.

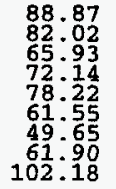



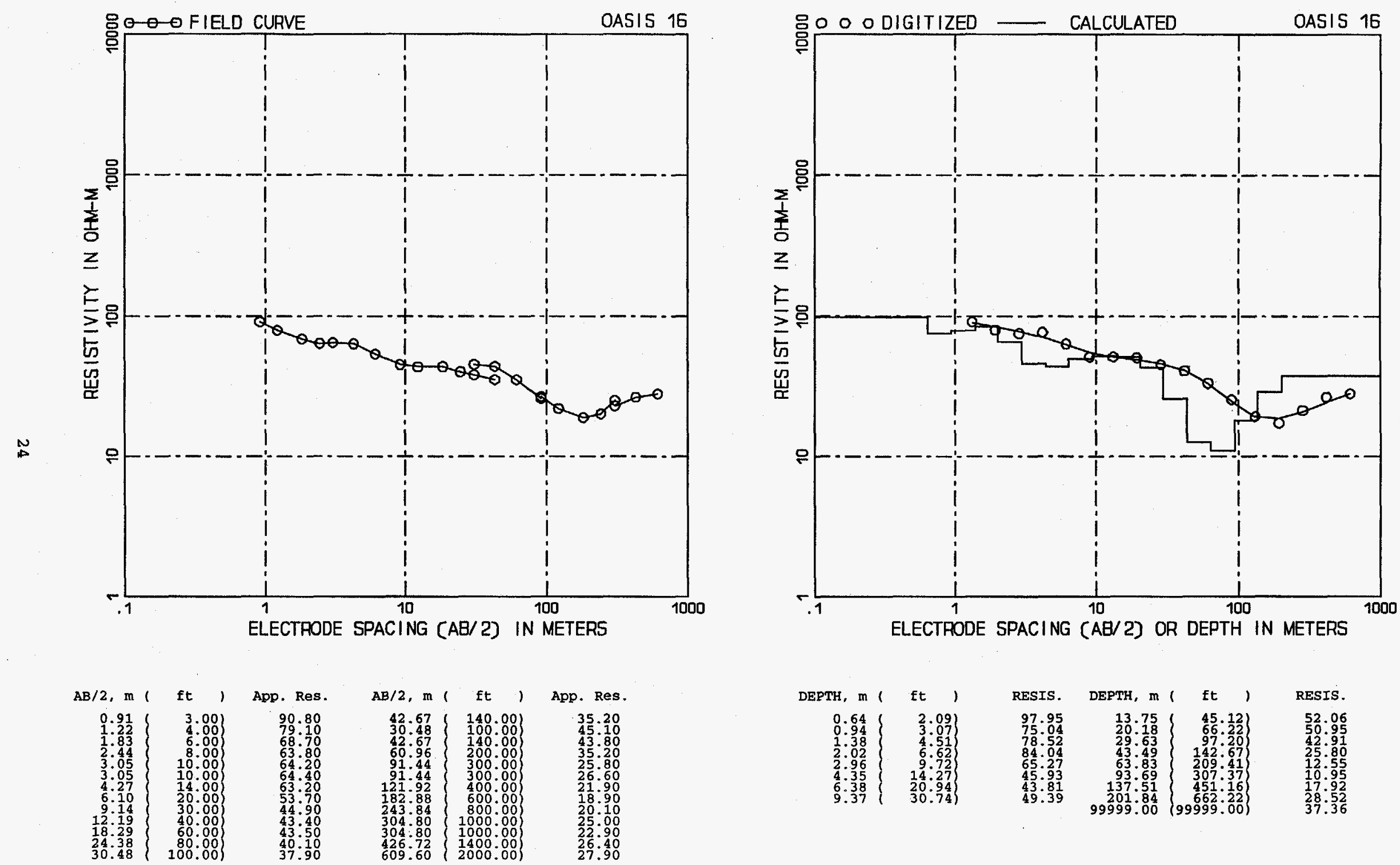

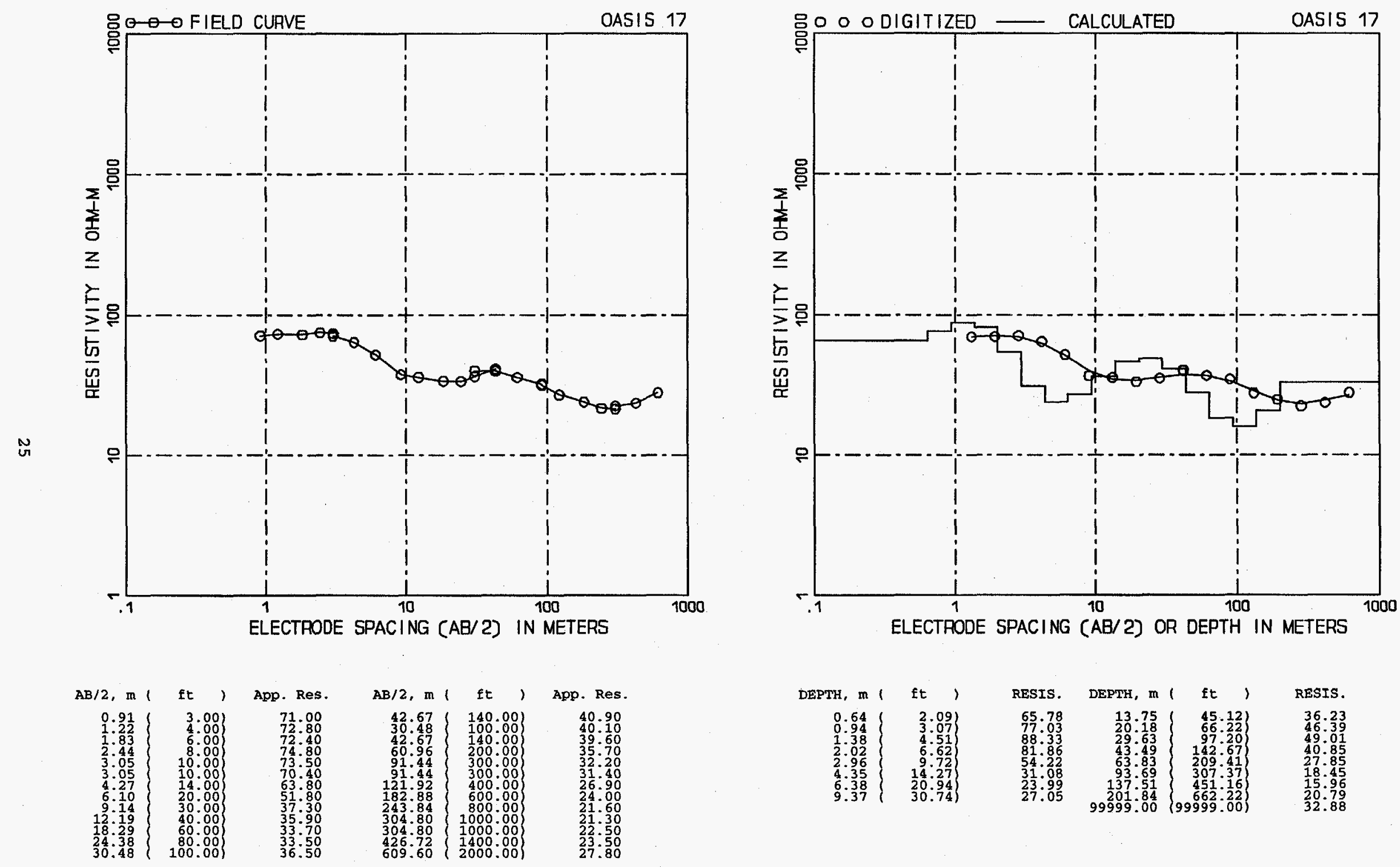

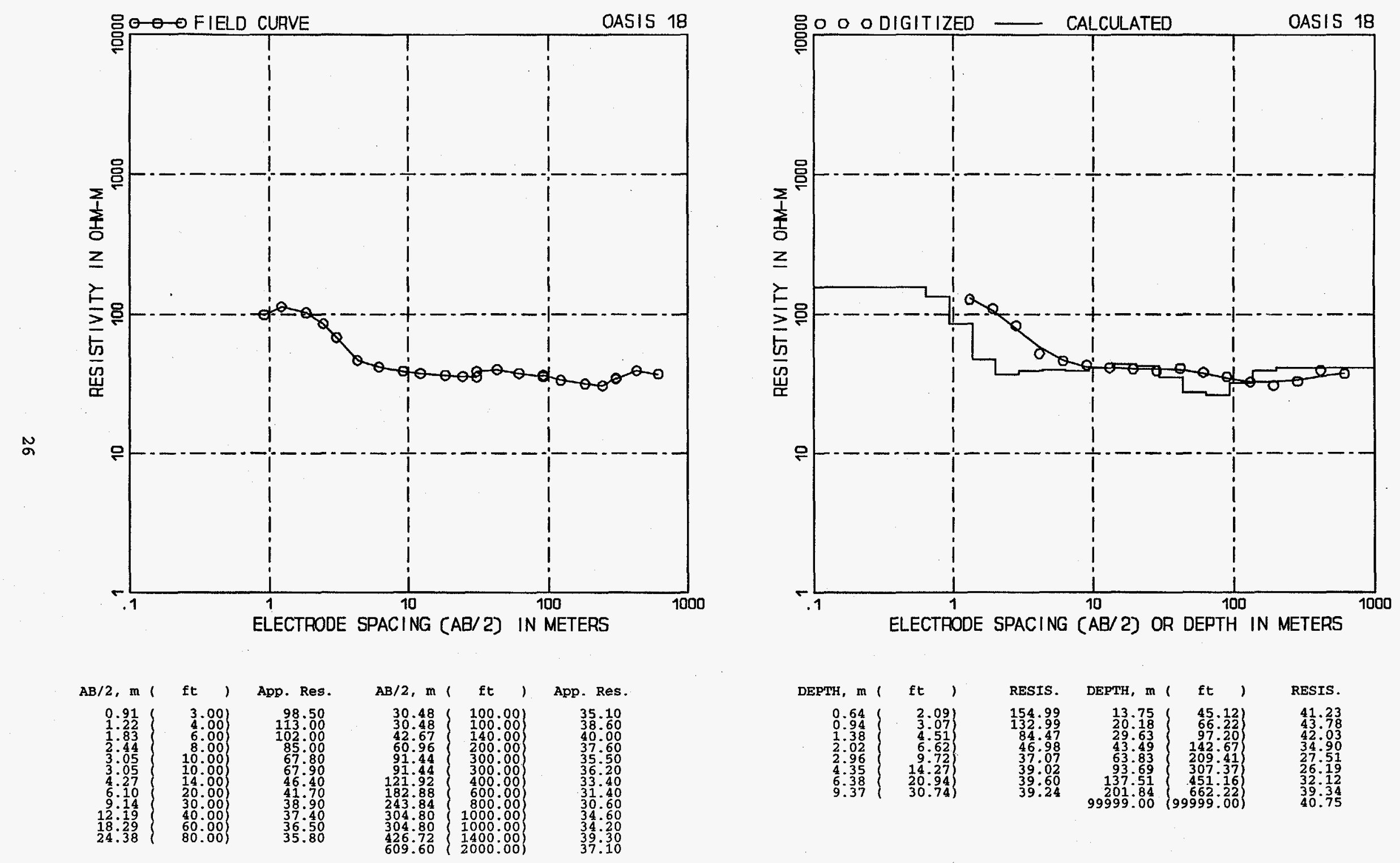

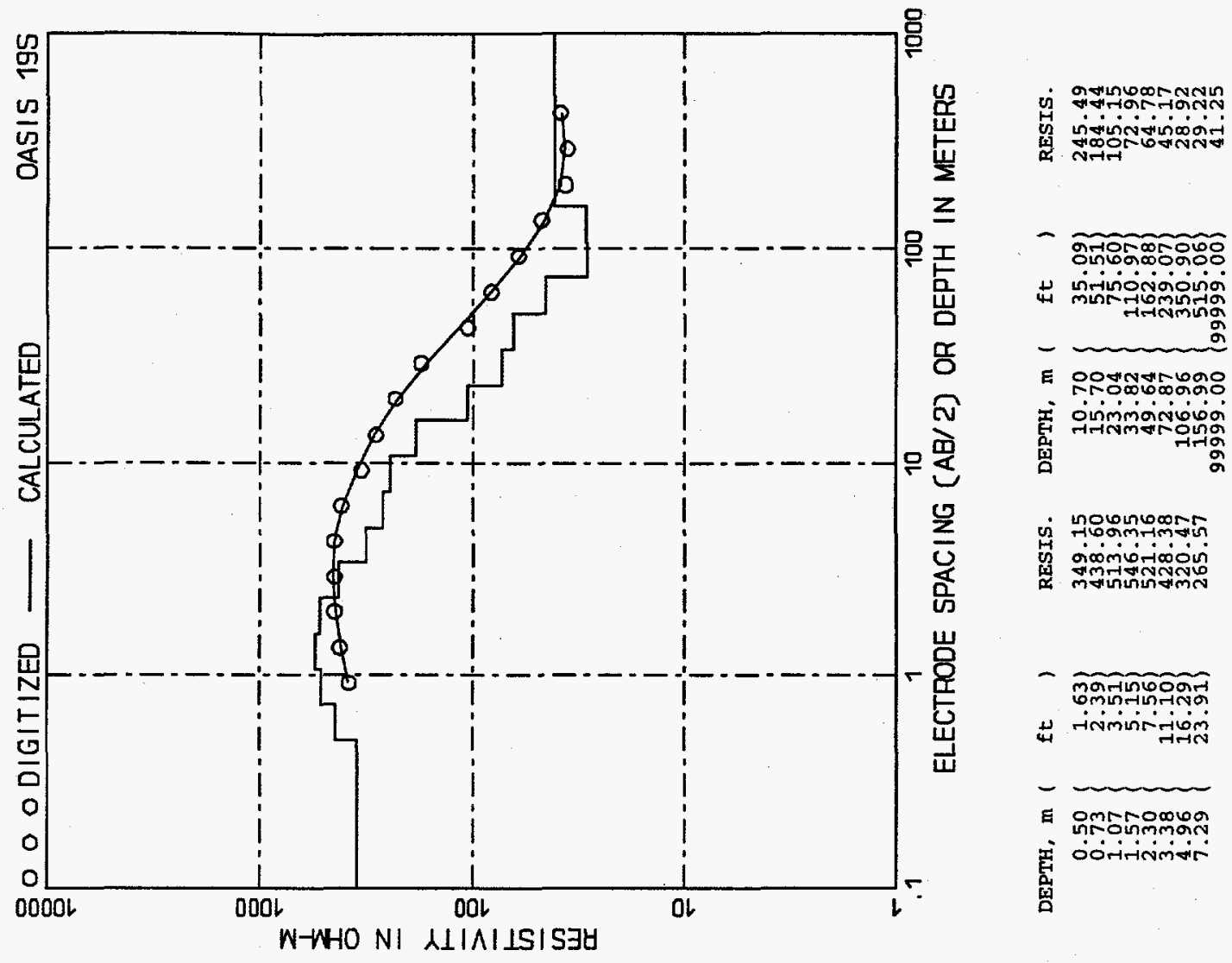

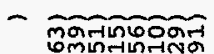

क्ष नirminifiom

$-$

⿷ ำกำ

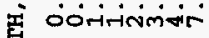

罟

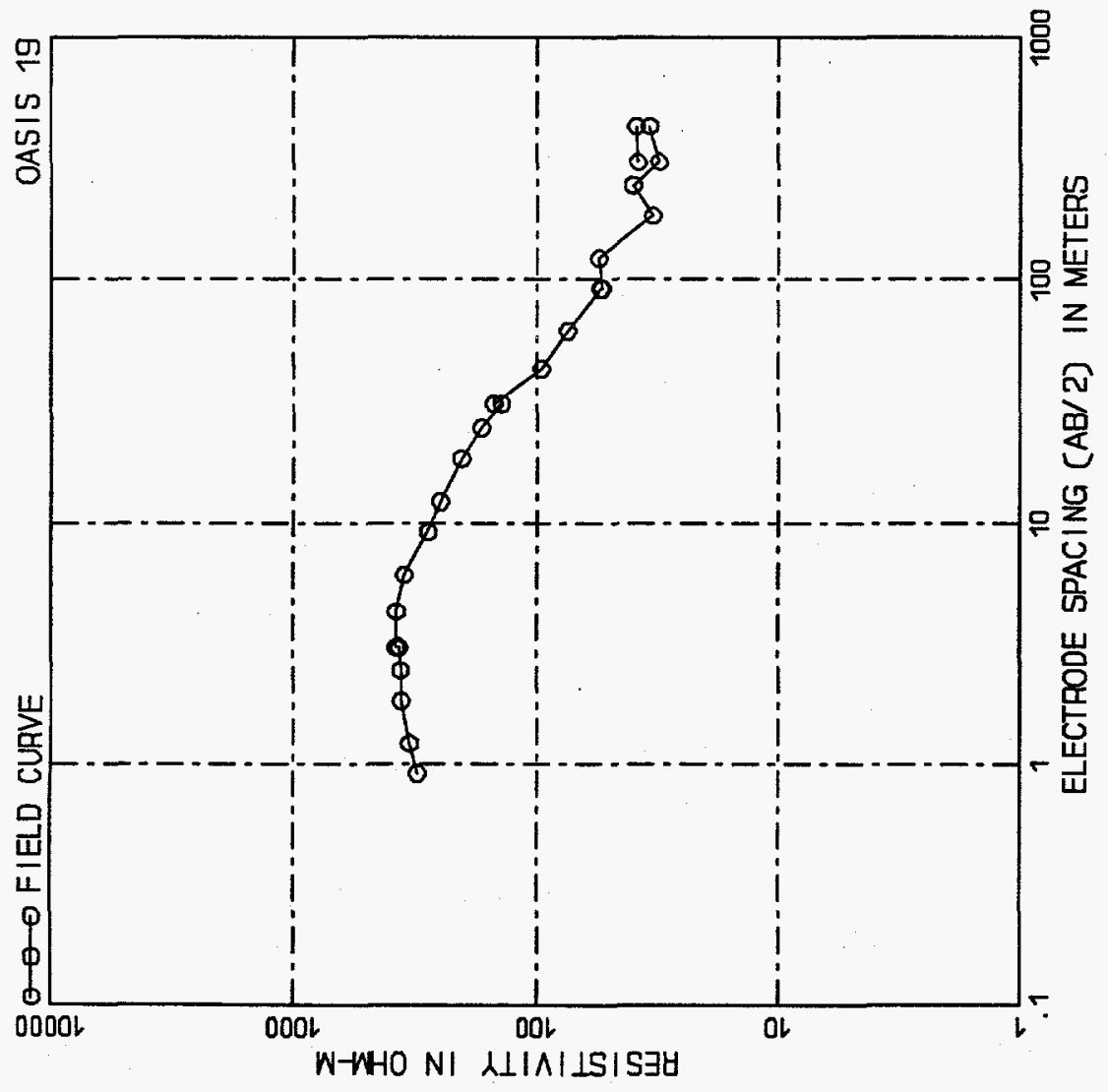

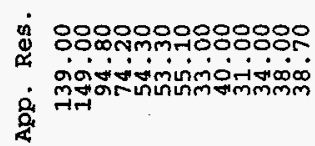

-

4

नननलMmmis

(1)

स+6

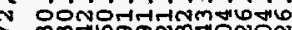

के

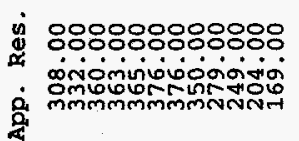

- 008080808008

4 mंजि0

-

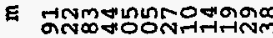

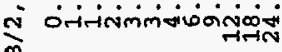



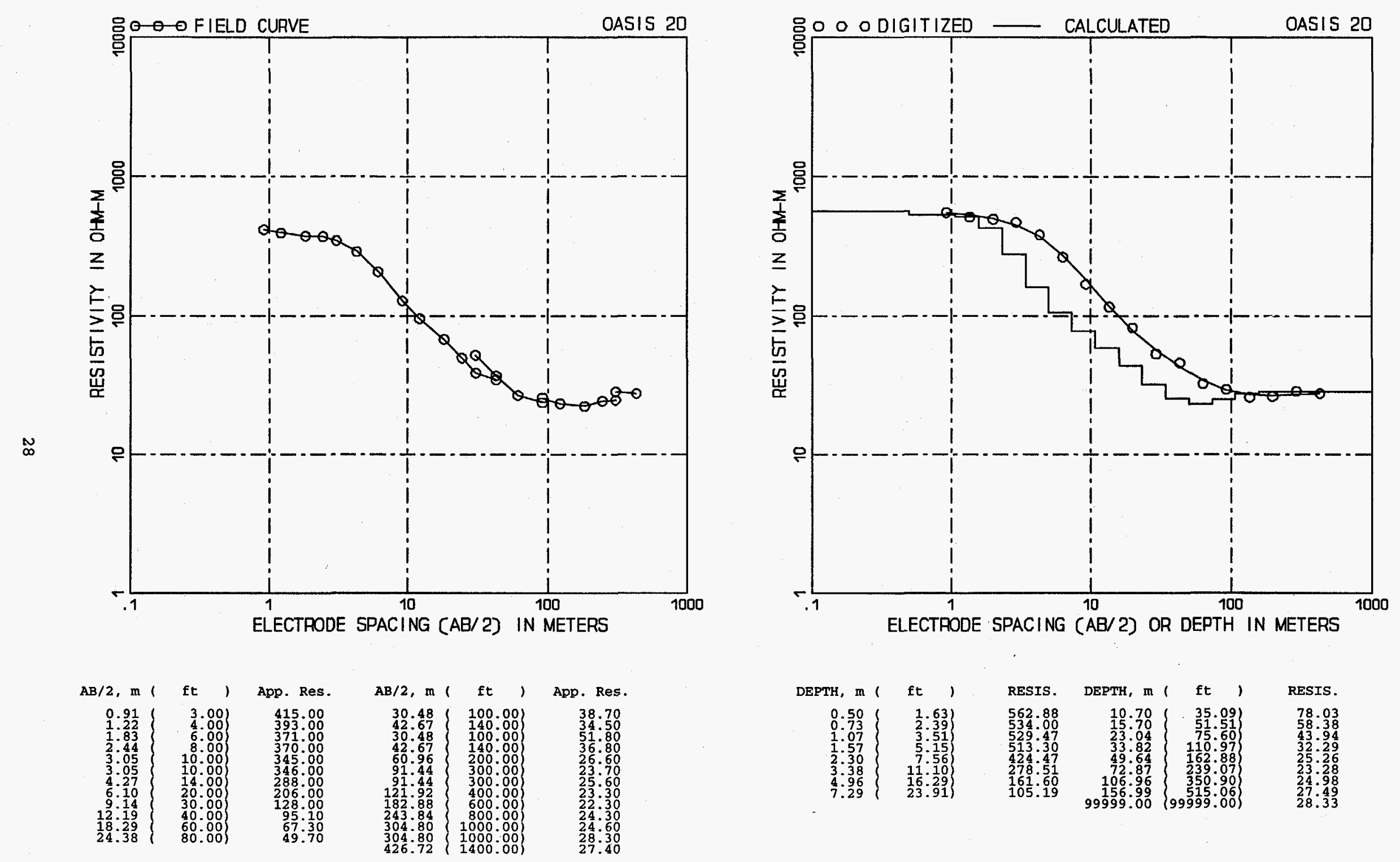

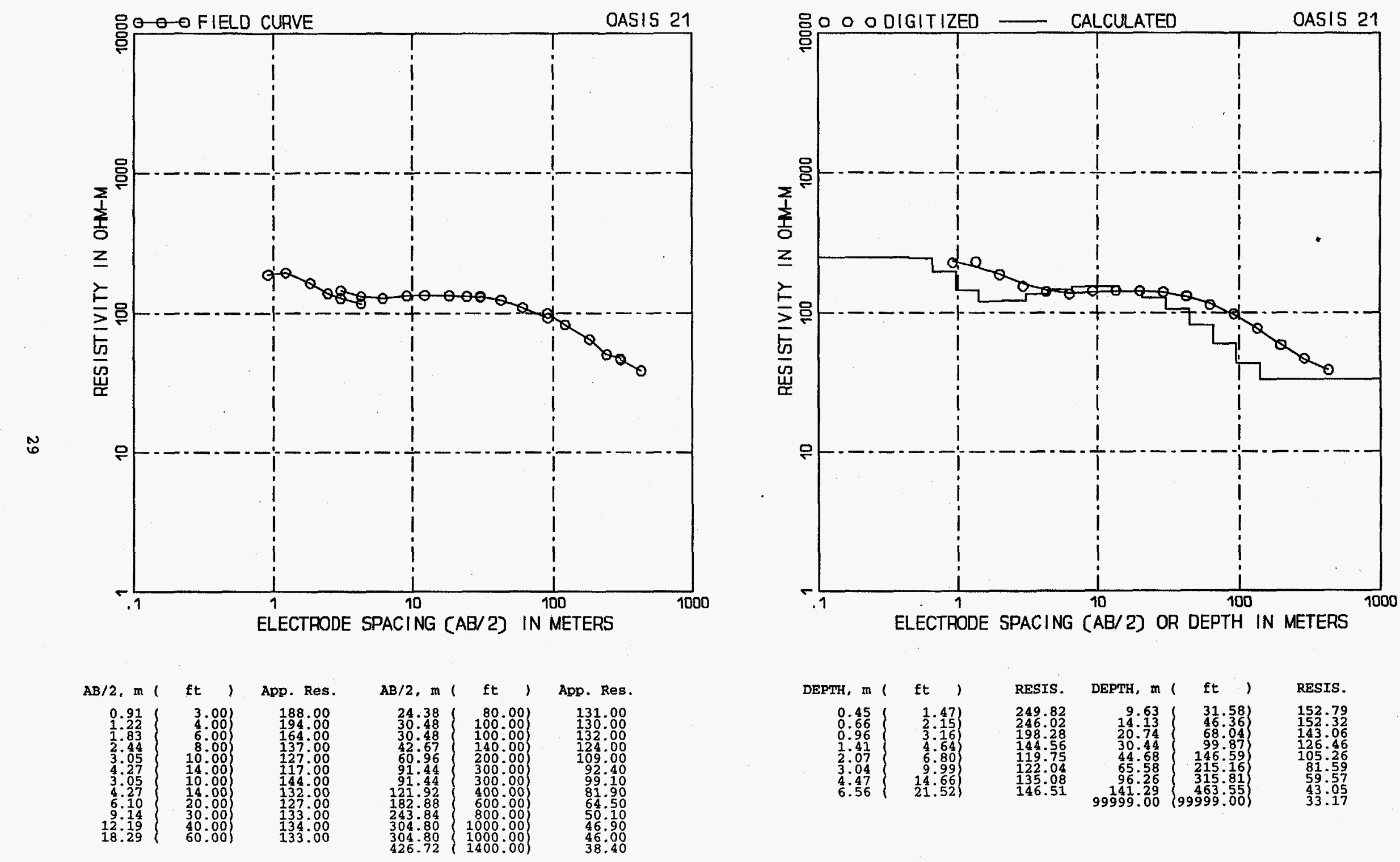

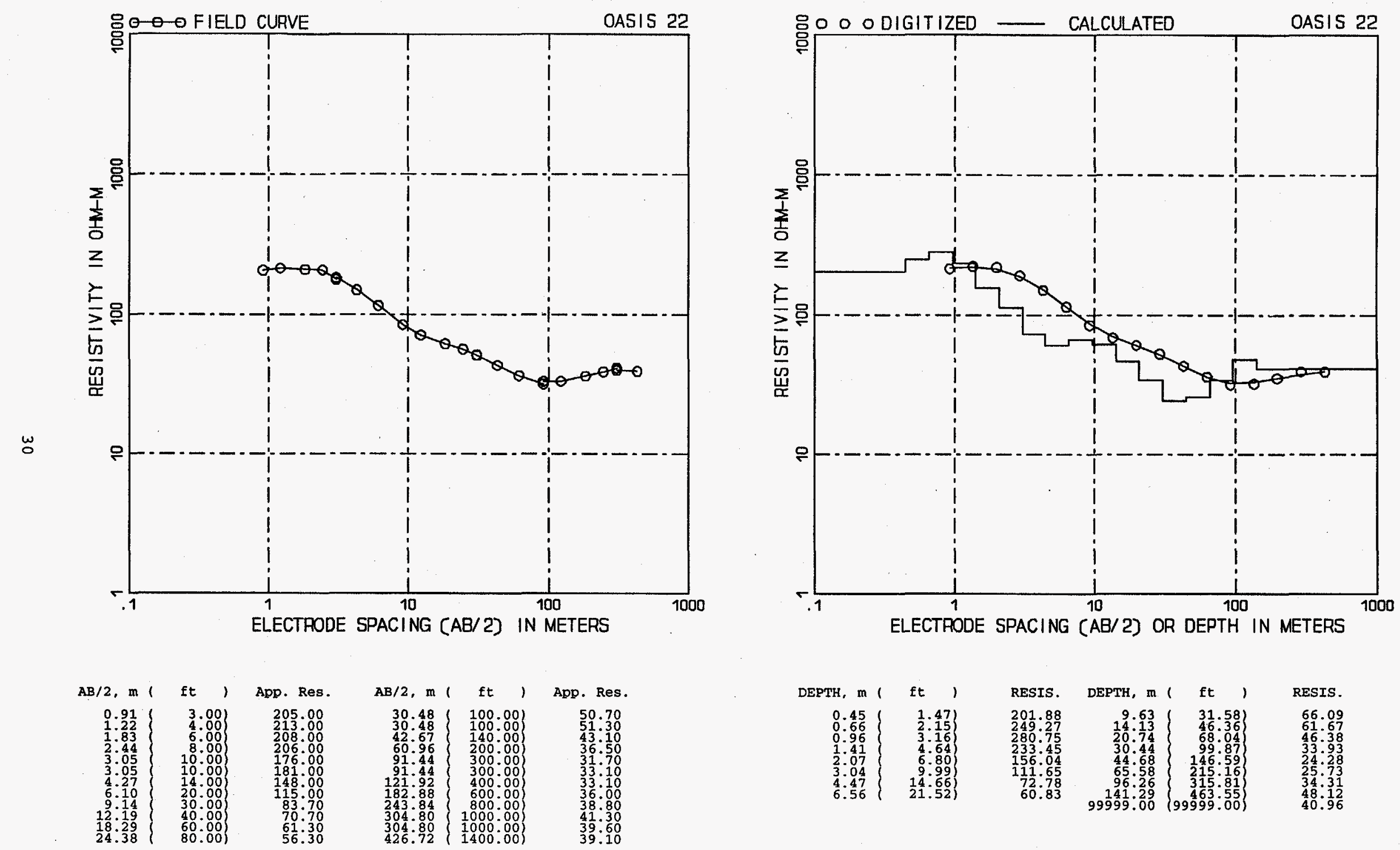

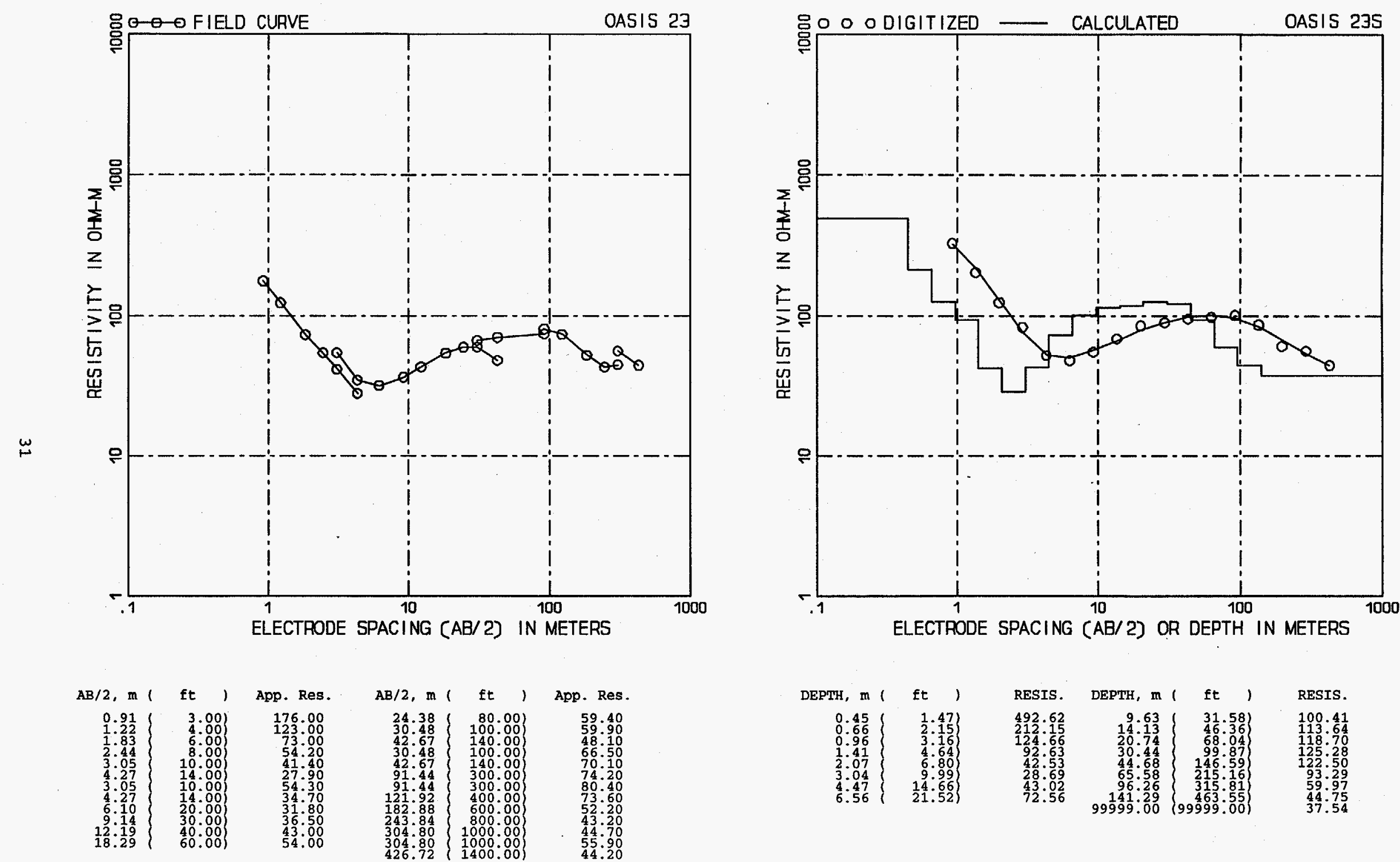

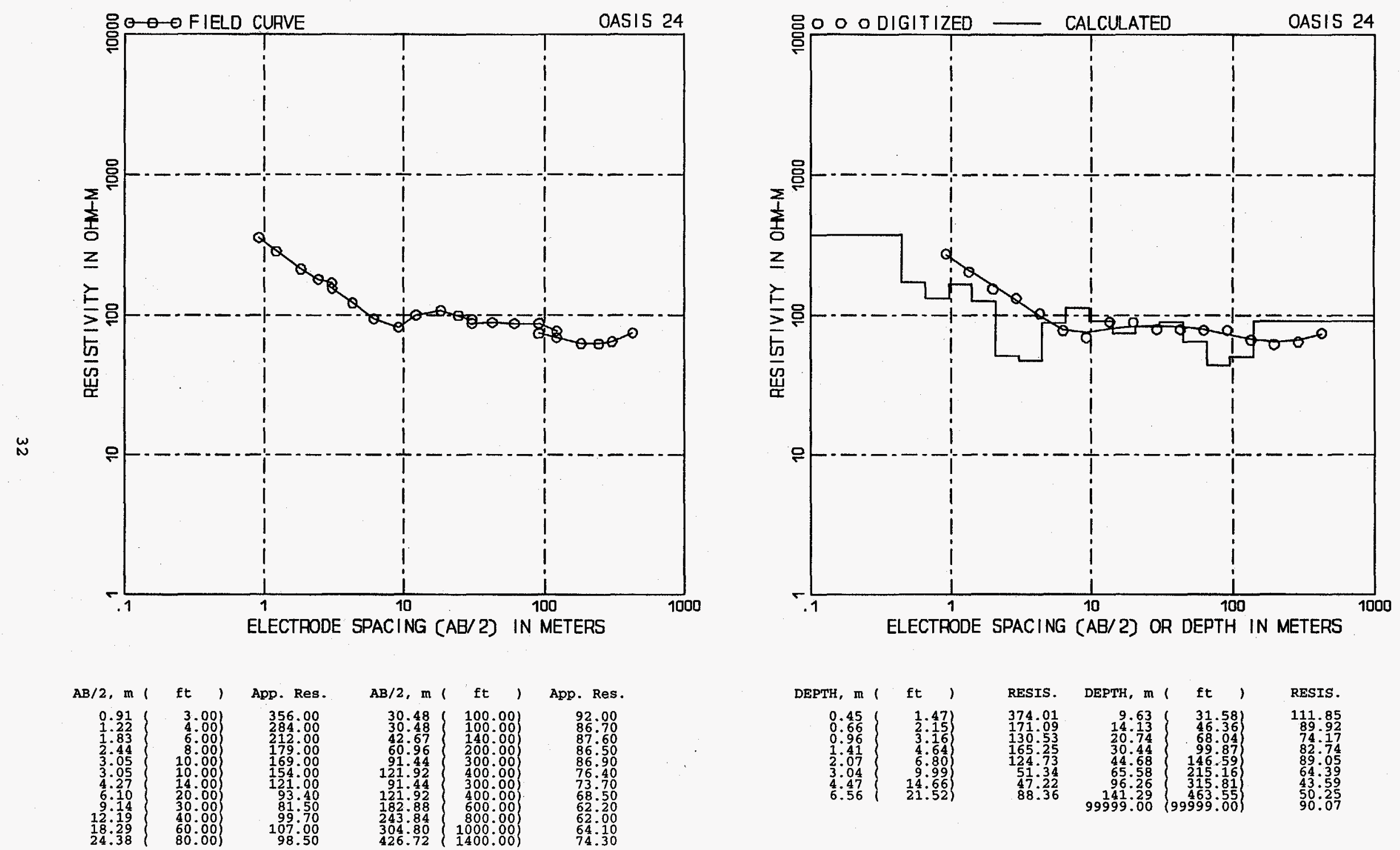

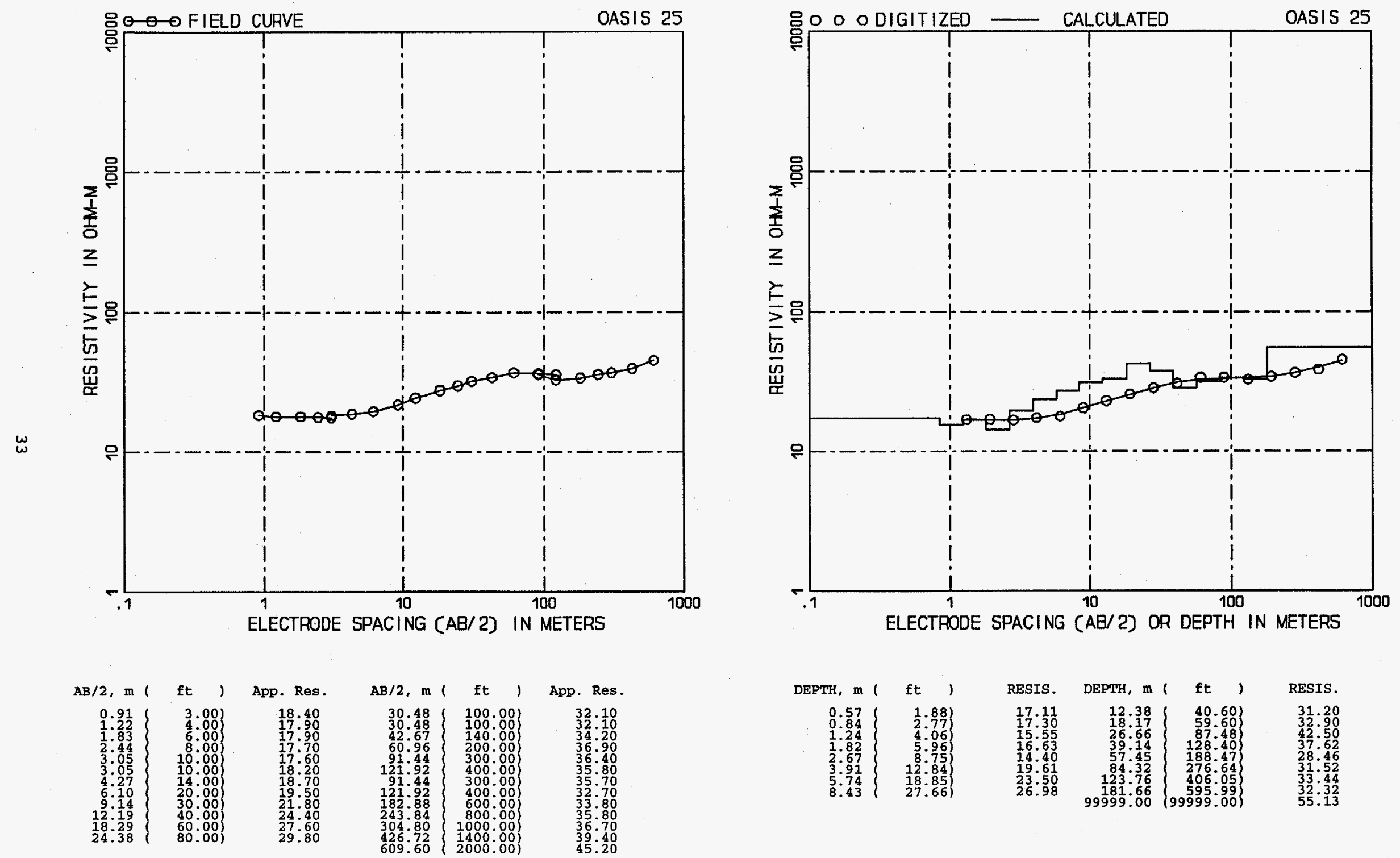

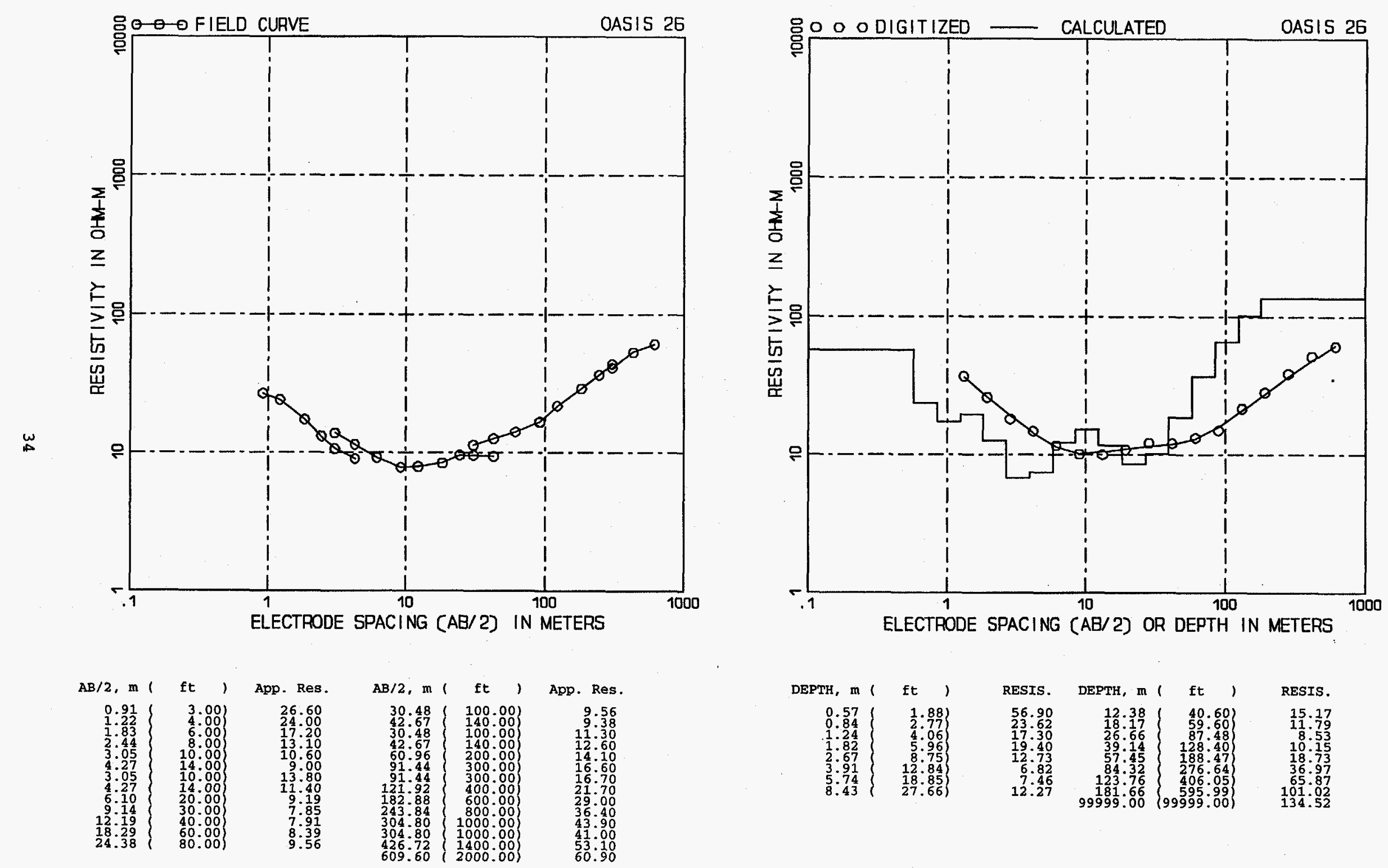

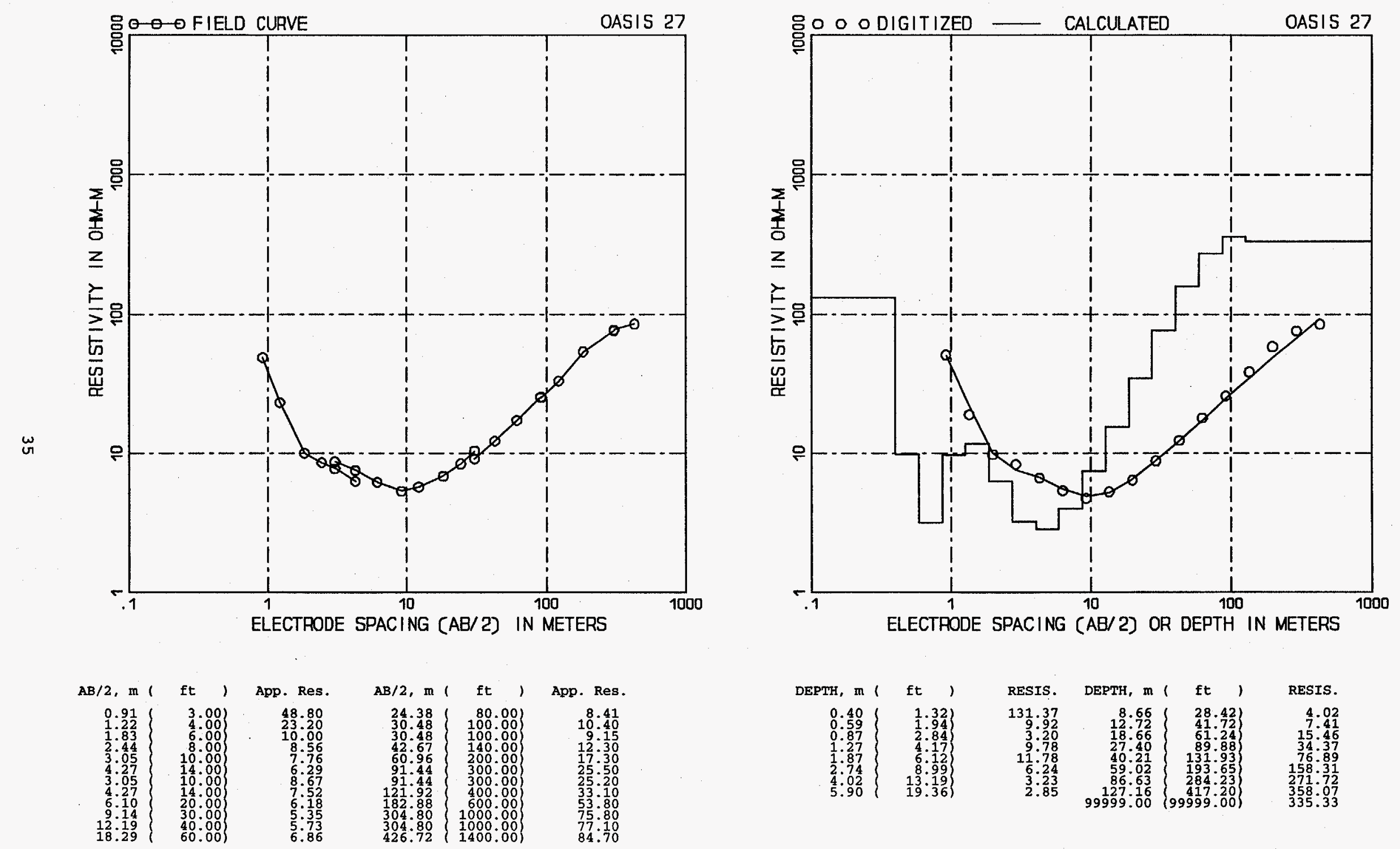

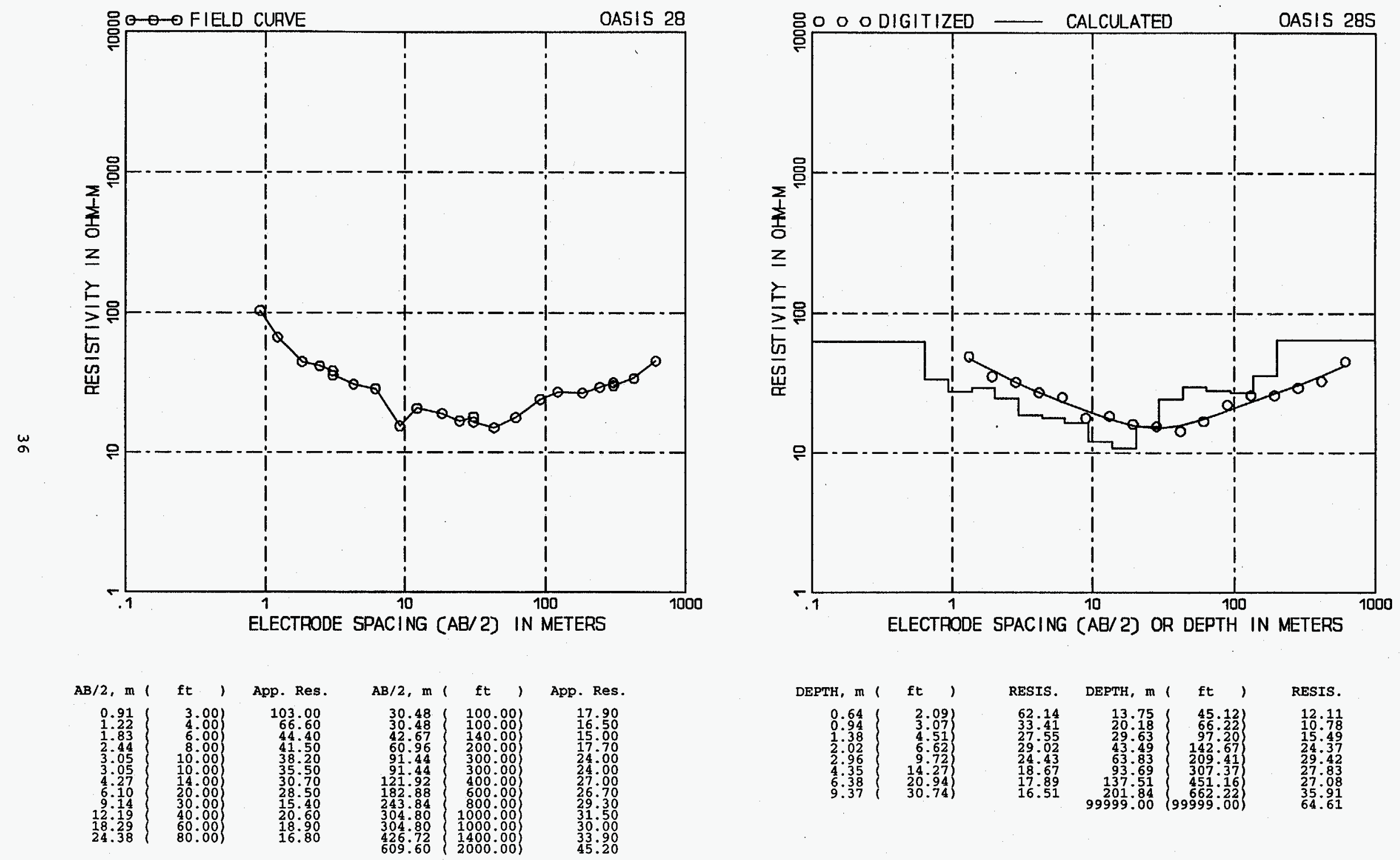

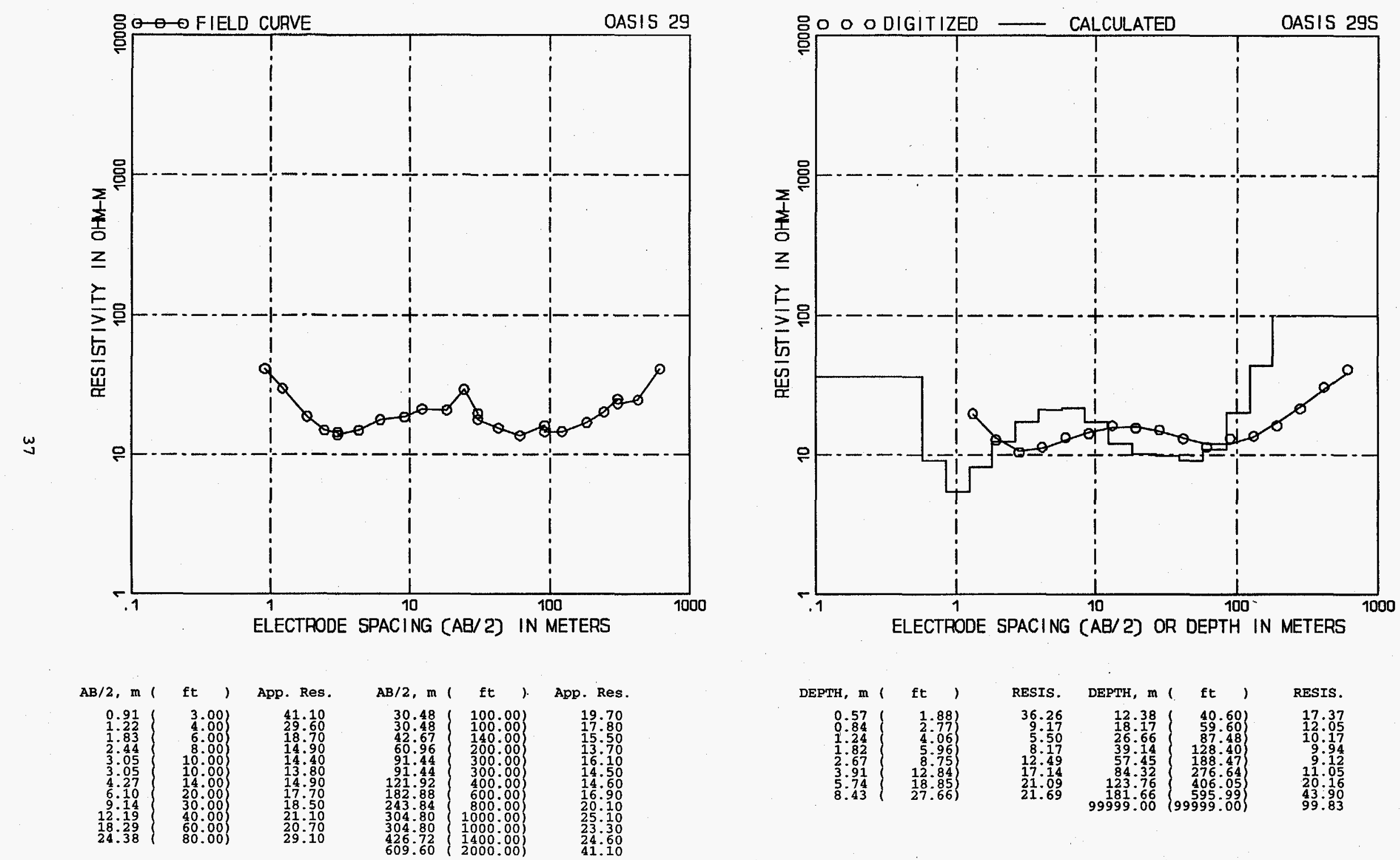

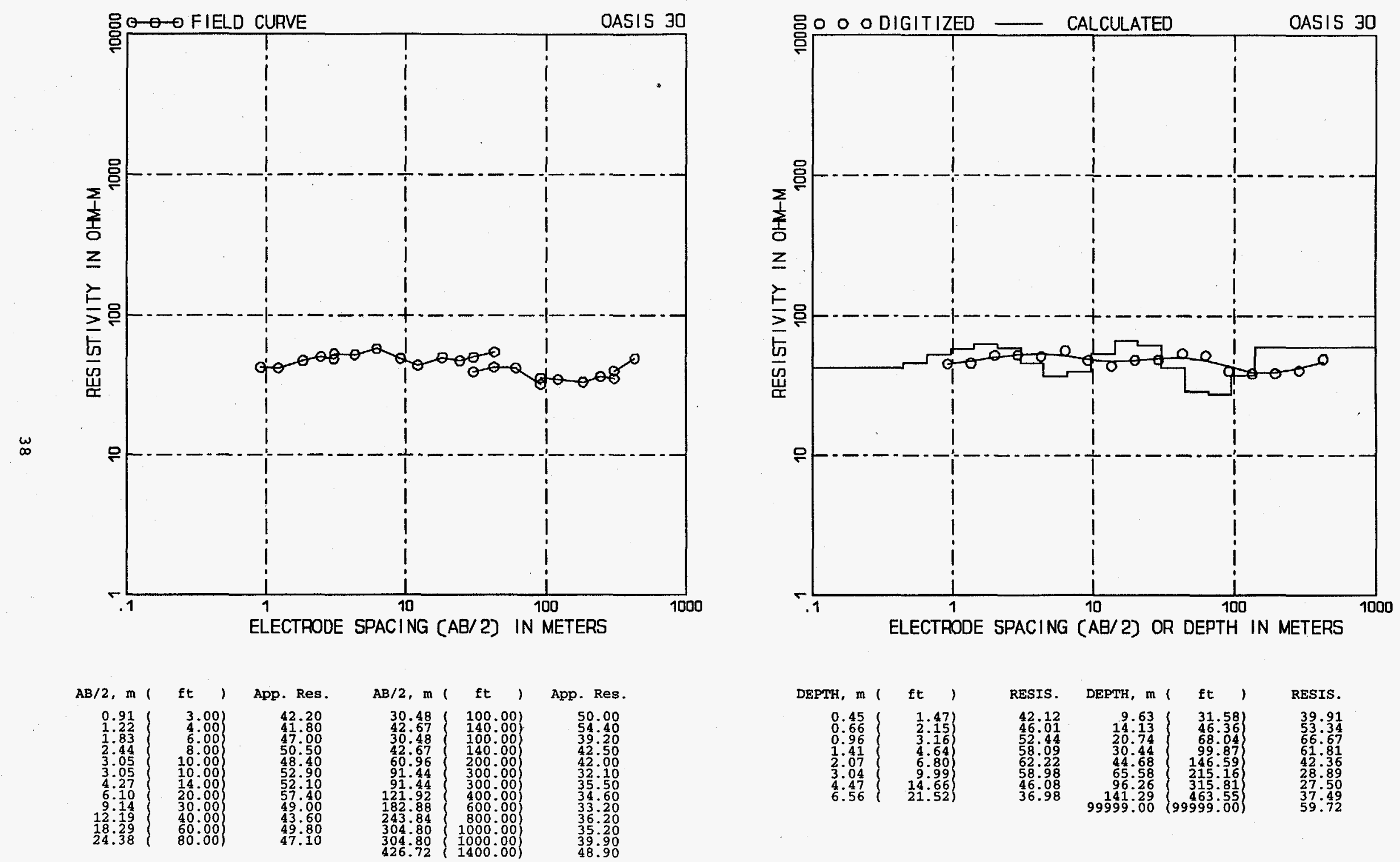

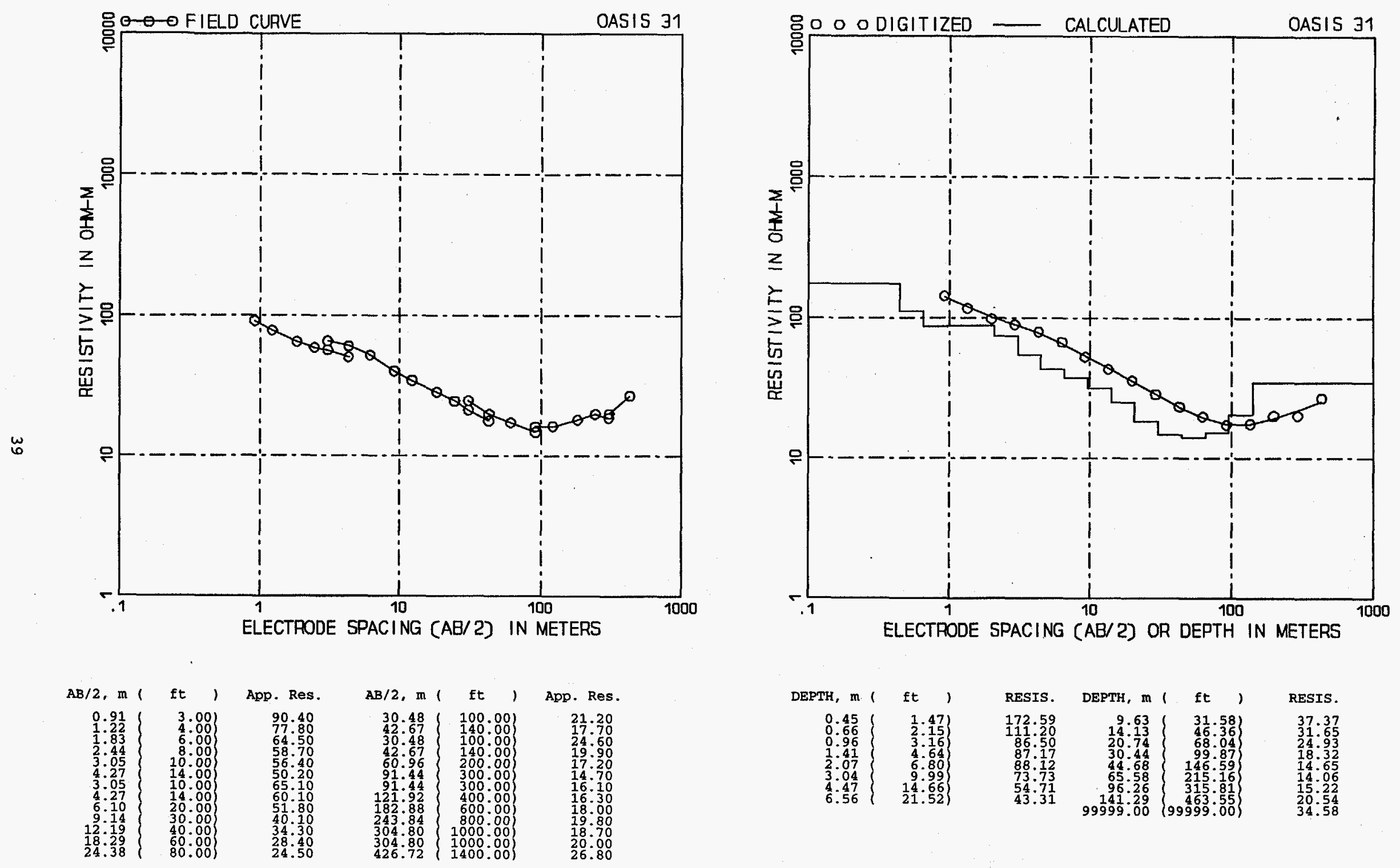

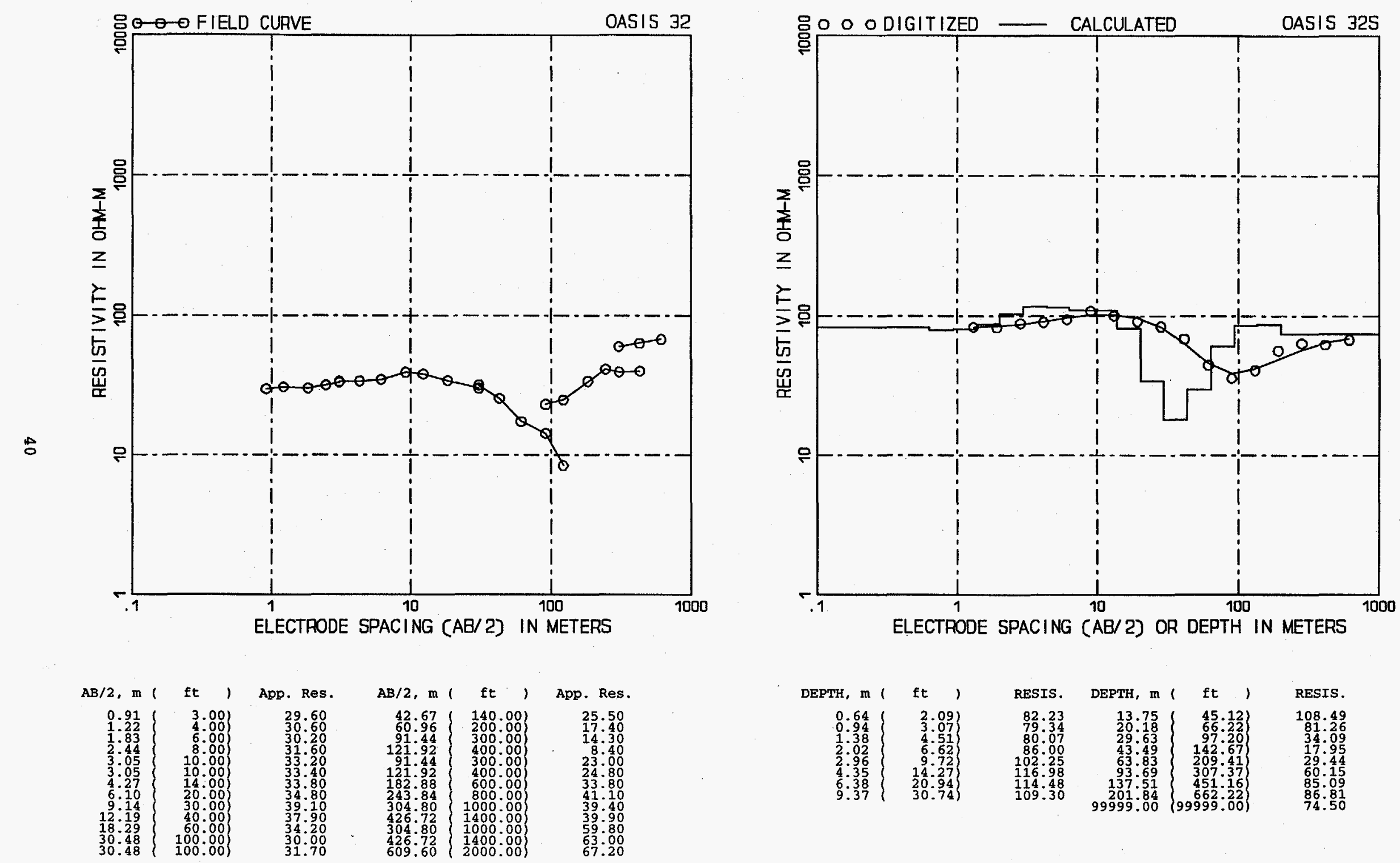

RESIS.

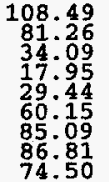



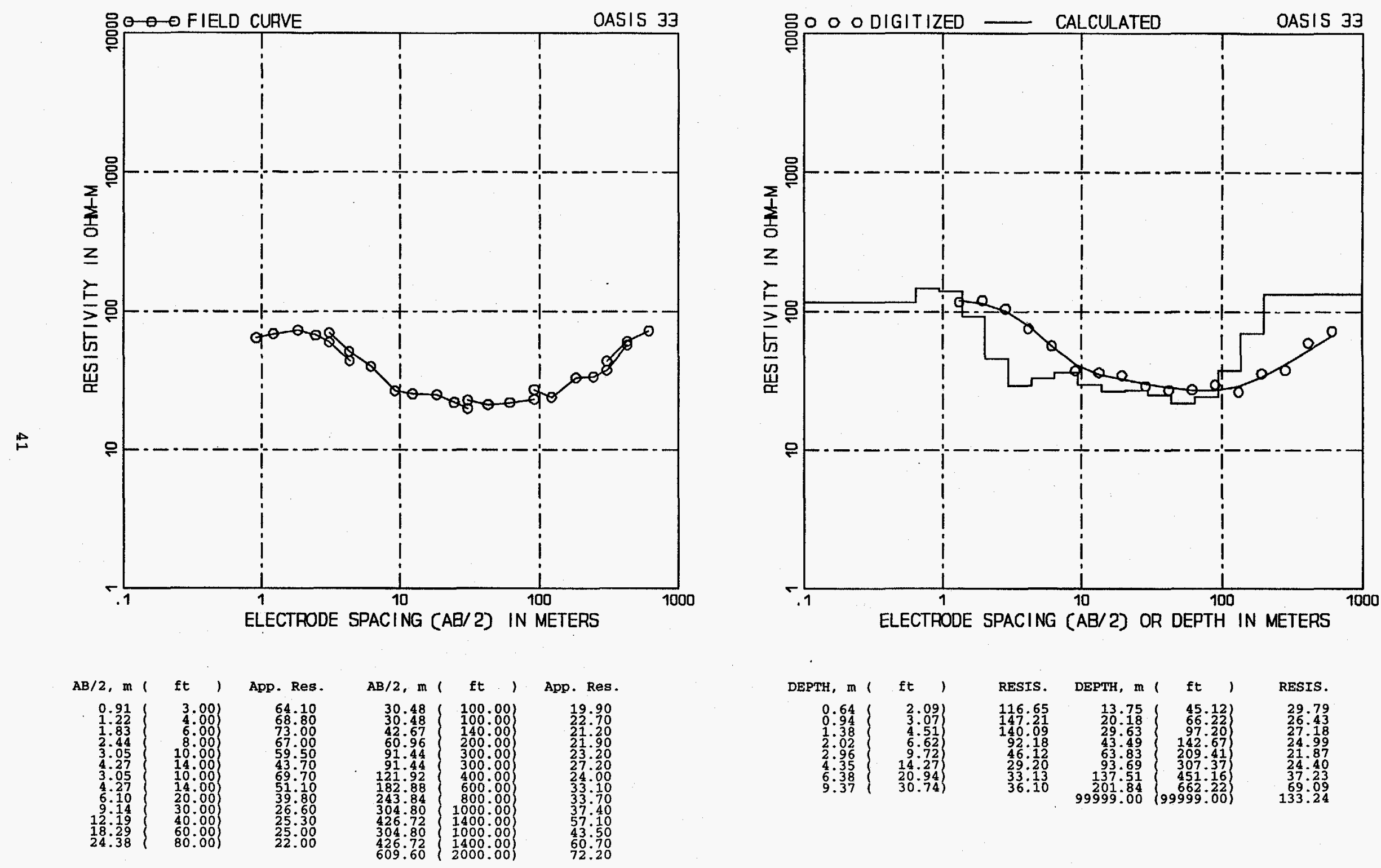

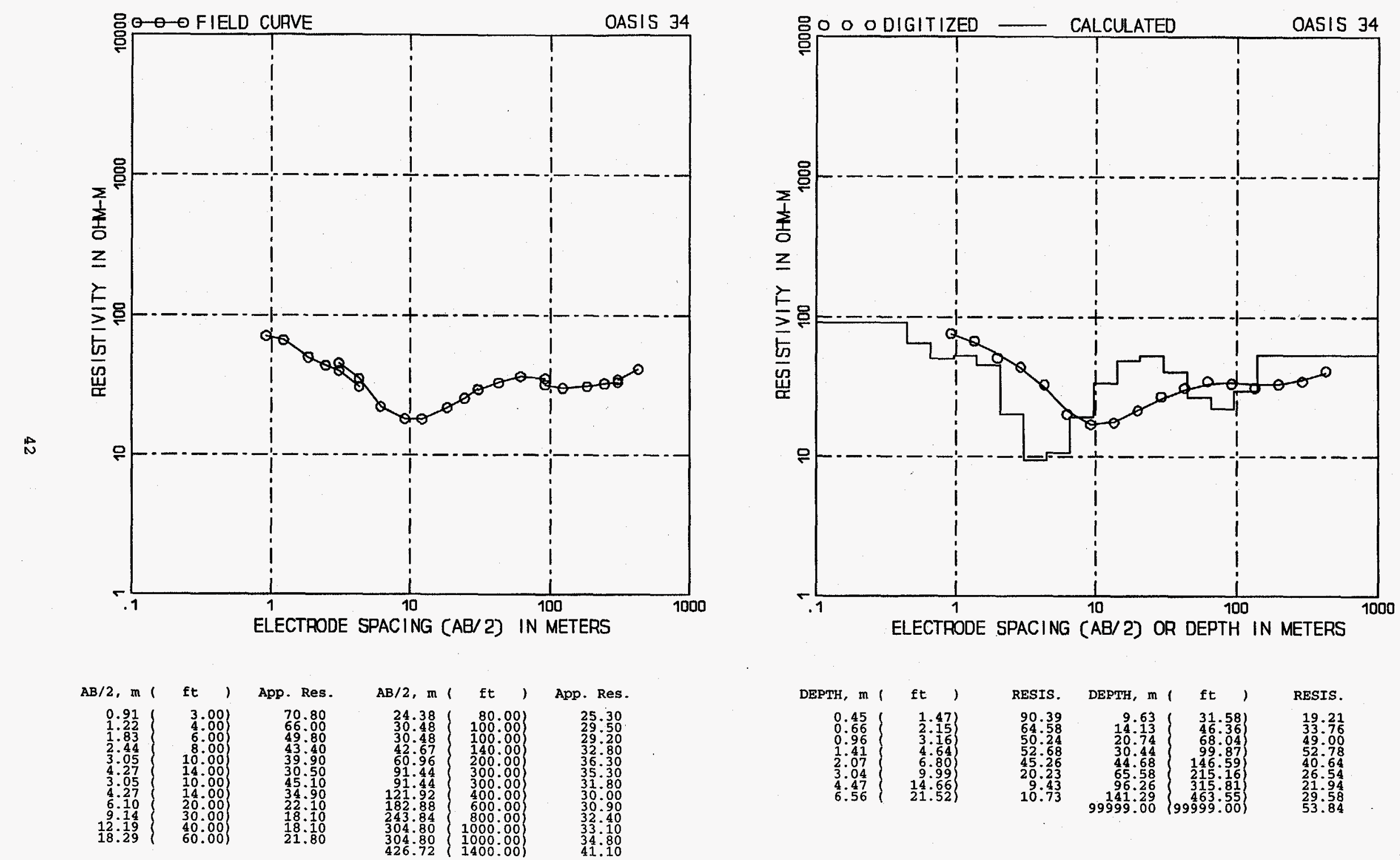

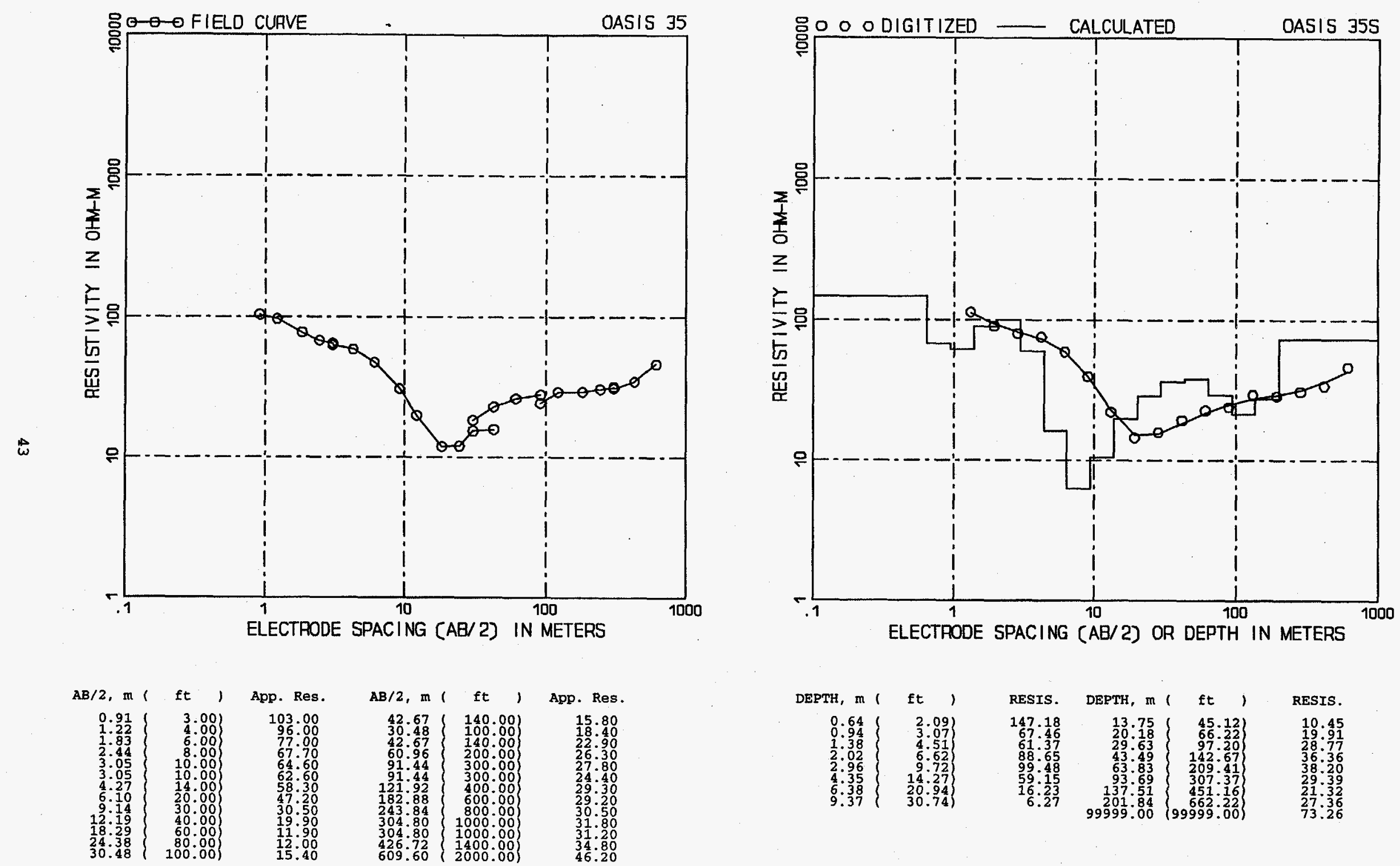

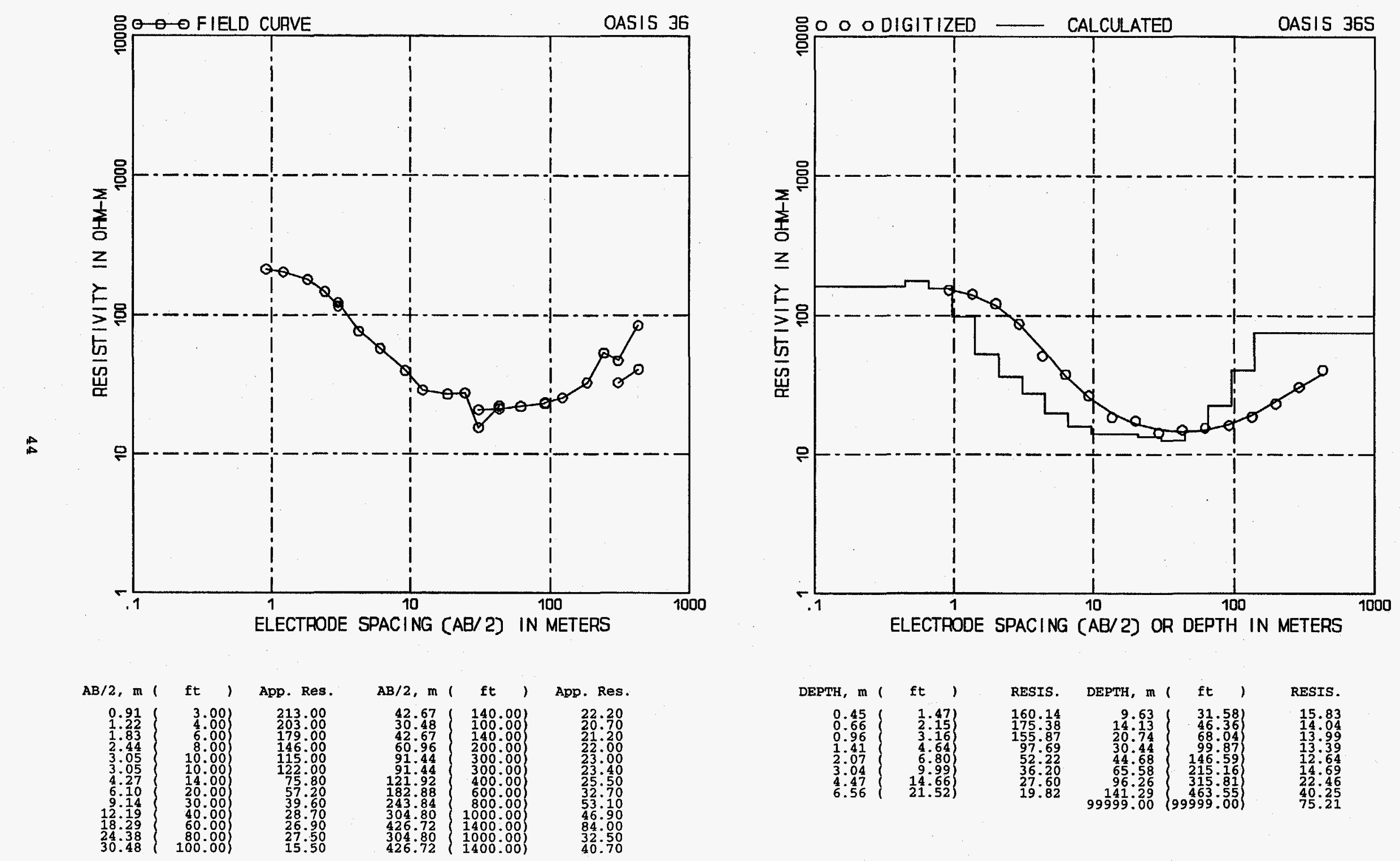

RESIS. 